\title{
An Analysis of Quit and Dismissal Determinants between 1988 and 1999 using the Bivariate Probit Model ${ }^{*}$
}

\author{
Veronica I. F. Orellano* \\ Paulo Picchetti***
}

\begin{abstract}
Excessive labor turnover may be considered, to a great extent, an undesirable feature of a given economy. This follows from considerations such as underinvestment in human capital by firms. Understanding the determinants and the evolution of turnover in a particular labor market is therefore of paramount importance, including policy considerations. The present paper proposes an econometric analysis of turnover in the Brazilian labor market, based on a partial observability bivariate probit model. This model considers the interdependence of decisions taken by workers and firms, helping to elucidate the causes that lead each of them to end an employment relationship. The Employment and Unemployment Survey (PED) conducted by the State System of Data Analysis (SEADE) and by the Inter-Union Department of Statistics and Socioeconomic Studies (DIEESE) provides data at the individual worker level, allowing for the estimation of the joint probabilities of decisions to quit or stay on the job on the worker's side, and to maintain or fire the employee on the firm's side, during a given time period. The estimated parameters relate these estimated probabilities to the characteristics of workers, job contracts, and to the potential macroeconomic determinants in different time periods. The results confirm the theoretical prediction that the probability of termination of an employment relationship tends to be smaller as the worker acquires specific skills. The results also show that the establishment of a formal employment relationship reduces the probability of a quit decision by the worker, and also the firm's firing decision in non-industrial sectors. With regard to the evolution of quit probability over time, the results show that an increase in the unemployment rate inhibits quitting, although this tends to wane as the unemployment rate rises.
\end{abstract}

Keywords: Turnover, Determinants of quits and dismissals and bivariate probit model.

JEL Codes: C35, J23, J24, J41.

\footnotetext{
Submitted in April 2003. Revised in October 2004

${ }^{* *}$ E-mail: orellano@fgvsp.br

***E-mail: pichetti@usp.br
} 


\section{Introduction}

The present paper provides an empirical analysis of quit and dismissal determinants. Therefore, it sheds some light on the determinants for labor turnover and its evolution in the analyzed time period (1988-1999).

The high labor turnover observed in Brazil ${ }^{1}$ is impressive and encourages the development of empirical studies, such as those by Barros et al. (1999b), Barros et al. (1999a), Corseuil et al. (2002) and Gonzaga (2003). The latter study is an in-depth discussion about the Brazilian employment protection legislation and the effectiveness of its incentive mechanisms in the reallocation of workers. This study contributes to the existing debate over the causes of excessive labor turnover in Brazil, having as major contribution the distinct analysis of quits and dismissals, based on the information given by workers about whose initiative it was to terminate the employment contract. This analysis was possible thanks to the information obtained from PED/SEADE/DIEESE. In this context, we also sought to investigate the effect of changes in the Brazilian labor market regulation - implemented in November 1988 by the new Constitution ${ }^{2}$ - on the probabilities of quits and dismissals.

PED (Employment and Unemployment Survey) data were collected at the individual level, which allowed for the correlation test through a cross-sectional analysis, using the information available about each individual and his jobs. Such tests were performed using the estimation of a bivariate probit model with partial observability. The proposed estimation procedure is based on the joint modeling of the utility maximizing behavior, involving both firms and employees. The econometric model and the data are described in Sections 1 and 2, respectively.

Section 3 describes each covariate used for the estimations, and discusses their inclusion based on the economic theory. This is done for the characteristics of workers and firms (and of the job contract as well), and for the variables that indicate changes in the macroeconomic environment. This includes a discussion about the possible effects produced by a change in the employment protection legislation on the probabilities of quits and dismissals.

Section 4 shows the results obtained with the econometric tests. The results were stratified according to sectors of economic activity, which enables the comparison between the statistically significant variables for the determination of quit and dismissal probabilities in each sector.

The last section concludes.

\footnotetext{
${ }^{1} \mathrm{~A}$ manifestation of high turnover would be the large percentage of workers who do not stay on their jobs for two years. Considering only those workers with a formal job contract, the average of this percentage in Brazil amounted to $48.6 \%$ between 1990 and 2000, according to the data available from the Annual Records of Social Information (RAIS).

${ }^{2}$ The changes implemented by the new constitution increased variable labor costs as well as layoff costs for the firms, since the penalty for unfair dismissal went from $10 \%$ of the amount accumulated in the FGTS (seniority severance payment fund) account, to approximately $40 \%$.
} 


\section{Proposal for the Empirical Study: The Bivariate Probit Model}

Poirier (1980) regards the bivariate probit model as ideal to analyze situations in which two agents have to individually make a binary choice, and these choices are correlated with each other. For instance, the author presents a situation analyzed by Gunderson (1974), in which the probability of a trainee being hired by the firm which provided the training course was estimated. In this situation, after the training period, the firm should decide whether it would hire the trainee. And the trainee should decide whether he wants to be hired by the firm.

The problem we want to analyze in this study is quite similar to the "trainee case" presented by Gunderson (1974) and Poirier (1980). In this study, employees are observed during a given month of the sample period, and then observed again one year later. In the second observation, the employment relationship may have been maintained or broken by any of the parties, or even broken by both parties. Thus, the idea is that over one year of observation, the firm should decide whether it would maintain the employment relationship. The employee, in his turn, should decide whether to quit or not. Just like in the trainee case, these decisions are correlated.

As Poirier (1980) puts it, the modeling of this situation becomes clearer after placing the problem in an analytical framework in which the two decision-making agents maximize their utility functions.

The firm's binary choice is represented by $y_{f}=0,1$ (where 1 refers to the maintenance of the employment relationship and 0 refers to the dismissal of an employee); whereas the employee's choice is represented by $y_{e}=0,1$ (where 1 refers to the decision to keep the job and 0 refers to his decision to quit). As previously mentioned, these decisions concern a one-year period. Considering vector $W$, with fixed observable characteristics of each firm, each employee and each employment relationship, we assume utility functions of the form:

$$
\begin{aligned}
& U_{f 0}=g_{f 0}\left(W, y_{e}^{*}\right)+\eta_{f 0} \\
& U_{f 1}=g_{f 1}\left(W, y_{e}^{*}\right)+\eta_{f 1}
\end{aligned}
$$

for the two possible choices made by the firm. Analogously, employees presumably have utility functions of the form:

$$
\begin{aligned}
& U_{e 0}=g_{e 0}\left(W, y_{f}^{*}\right)+\eta_{e 0} \\
& U_{e 1}=g_{e 1}\left(W, y_{f}^{*}\right)+\eta_{e 1}
\end{aligned}
$$

where, for $j=f, e$ and $i=0,1$, we have that: $g_{j i}$ are deterministic functions; $\eta_{j i}$ are unobservable random factors; and each $y^{*} j$ is equal to $\left(U_{j 1}-U_{j 0}\right)$, representing the "tendency" of agent $j$ towards choice $y_{j}=1$, or the "preference" of agent $j$. 
It should be noted that these functions involve an important hypothesis. This hypothesis posits that the utility an agent attributes to each of his options depends on the other agent's "preference." This means that the model deals with the hypothesis that each agent perceives, at least in part, the other agent's "preference," and this influences his own decision. This hypothesis is supported by lines of research discussed in Section 3, as they show that each agent involved in an employment relationship needs to guarantee that the other party is also committed. Regardless of theoretical developments, we must say that this idea is quite intuitive. As Ehrenberg and Smith (1994, pg. 340) put it "While we may talk of a quit as "worker-initiated," the fact that an employer did not choose to take steps to retain potential quitters would seem to imply that the employer believed keeping them was not worth the cost."

Following Poirier (1980), we assume that:

$$
\begin{gathered}
g_{f 1}\left(W, y_{e}^{*}\right)-g_{f 0}\left(W, y_{e}^{*}\right)=\gamma_{f} y_{e}^{*}+X \delta_{f} \\
g_{e 1}\left(W, y_{f}^{*}\right)-g_{e 0}\left(W, y_{f}^{*}\right)=\gamma_{e} y_{f}^{*}+X \gamma_{e} \\
\eta_{f 1}-\eta_{f 0}=\epsilon_{f} \\
\eta_{e 1}-\eta_{e 0}=\epsilon_{e}
\end{gathered}
$$

where $X$ is a covariate vector; $\delta_{f} \delta_{e}$, are vectors of unknown parameters; $\gamma_{f}, \gamma_{e}$, are unknown parameters; and

$$
\left[\begin{array}{c}
\varepsilon_{f} \\
\varepsilon_{e}
\end{array}\right] \sim N\left(0,\left[\begin{array}{ll}
W_{f f} & W_{f e} \\
W_{e f} & W_{e e}
\end{array}\right]\right)
$$

Therefore:

$$
\begin{gathered}
y_{f}^{*}=\gamma_{f} y_{e}^{*}+X \delta_{f}+\epsilon_{f} \\
y_{e}^{*}=\gamma_{e} y_{f}^{*}+X \delta_{e}+\epsilon_{e}
\end{gathered}
$$

which, according to the hypothesis of stochastic utility maximization, means that agent $j$ will choose option 1 if $y_{j}^{*}>0$. That is, $y_{j}=1$ if $U_{j 1}>U_{j 0}$, for $j=f, e$. Defining:

$$
\begin{gathered}
\beta_{e}=\left(1-\gamma_{f} \gamma_{e}\right)^{-1}\left(\delta_{e}-\gamma_{e} \delta_{f}\right) \\
\beta_{f}=\left(1-\gamma_{f} \gamma_{e}\right)^{-1}\left(\delta_{f}-\gamma_{f}-\delta_{e}\right) \\
\left.\left.\nu_{e}=\left(1-\gamma_{f} \gamma_{e}\right)^{-1}\right) \epsilon_{e}-\gamma_{e} \epsilon_{f}\right)
\end{gathered}
$$

we finally have the following reduced-form equations: 


$$
\begin{gathered}
y_{e}^{*}=X \beta_{e}+\nu_{e} \\
y_{f}^{*}=X \beta_{f}+\nu_{f}
\end{gathered}
$$

Thus, two facts allow the interdependence of utility functions of the two individuals. The first one, which was previously mentioned, is that the utility of each individual is specified as being dependent upon the other individual's "tendency." The second one is that both unobservable stochastic components are potentially correlated.

Then, even though equations(5) correspond to two separate univariate discretechoice models, they can benefit from joint estimation, which shows that the bivariate model is the most appropriate. This results directly from higher asymptotic efficiency in a context of maximum likelihood estimation, in the case in which $w_{f e}, w_{e f}$ and $\rho$ are different from zero.

Assuming the standard bivariate normal distribution as the "link" function, denoted by $F($.$) , we have the bivariate probit model, with log-likelihood function$ given by:

$$
\begin{aligned}
l\left(\beta_{f}, \beta_{e}, \rho\right) & =\sum_{i-1}^{N}\left\{y_{i f} y_{i e} 1 n F\left(X_{i} \beta_{f}, X_{i} \beta_{e}, \rho\right)\right. \\
& +y_{i f}\left(1-y_{i e}\left(1-y_{i e} 1 n\left[\phi\left(X_{i} \beta_{f}\right)-F\left(X_{i} \beta_{f}, X_{i} \beta_{e}, \rho\right)\right]\right.\right. \\
& +\left(1-y_{i f}\right) y_{i e} 1 n\left(\phi\left(X_{i} \beta_{e}\right)-F\left(X_{i} \beta_{f}, X_{i} \beta_{e}, \rho\right)\right] \\
& +\left(1-y_{i f}\right)\left(1-y_{i e}\left\{1 n\left[\rho\left(X_{i}, \beta_{f}\right)-F\left(X_{i} \beta_{f}, X_{i} \beta_{e}, X_{i}, \rho\right)\right]\right.\right. \\
& +\left(1-y_{i f}\right)\left(1-y_{i e}\left\{1 n\left[\phi\left(X_{i} \beta_{f}\right)-F\left(X_{i} \beta_{f}, X_{i} \beta_{e}, \rho\right)\right]\right.\right. \\
& \left.+1 n\left[\phi\left(X_{i} \beta_{e}\right)-F\left(X_{i}, \beta_{f}, X_{i}, \beta_{e}, \rho\right)\right]\right\}
\end{aligned}
$$

where $\phi($.$) is the standard univariate normal distribution, and N$ stands for the sample size.

The likelihood function shown above presupposes that there is enough information to distinguish each of the four possible combinations of decisions made by the firm and by the employee ( "keep/stay," "keep/quit," "fire/stay," and "fire/quit"). However, this is not an appropriate hypothesis to deal with the specific situation to be faced in this study. As will be discussed in the next section (data description), the only combination of decisions we can guarantee from the available observation is that in which both the employee and the employer jointly decide to maintain the employment relationship ( "keep/stay"), which is directly observed when the employee keeps the same job after one year.

When the employee does not hold the same job after one year, he informs us whether he quit or was fired. However, if he, for instance, informs us that he quit, 
we cannot be sure of what the firm's decisions would have been by the end of one year. Analogously, if the employee informs us that he was fired, we cannot be sure of what this employee's decision would have been by the end of one year. The dismissal by the employer might have occurred after a period in which the employee neglected his duties, perhaps while he was looking for another job.

In the specific case of the Brazilian labor market, the labor legislation encourages workers to strike a deal with firms, in which case, if they decide to quit, they ask to be formally dismissed (unfair dismissal); thus they are entitled to withdraw the balance of the FGTS account (Seniority Severance Payment Fund account). This casts further doubt on the answer "I was fired" as an actual representation of the employer's decision.

These considerations support the estimation of the partial observability bivariate probit model of Poirier (1980), in which, instead of observing $X_{i}, y_{f i}$ and $y_{e i}$, $i=1,2, \ldots, N$, we observe $X_{i}$ and $z_{i}, i=1,2, \ldots, N$, where

$$
\begin{gathered}
z_{i}=1 \\
z_{i}=0
\end{gathered}
$$

This means that from the four possible combinations of decisions made by the employee and the firm - "keep/stay," "keep/quit," "fire/stay" and "fire/quit" - it is possible to distinguish only the second one from the other three. In this context, the two equations necessarily have to be jointly estimated, given the arguments of asymptotic efficiency. The log-likelihood function is now equal to:

$$
l\left(\beta_{f}, \beta_{e}, \rho\right)=\sum_{i=1}^{N}\left\{z_{i}, \ln F\left(X_{i} \beta_{f}, X_{i} \beta_{e}, \rho\right)+\left(1-z_{i}\right) 1 n\left[1-F\left(X_{i} \beta_{f}, X_{i} \beta_{e}, \rho\right)\right]\right\}
$$

It results directly from the distribution of zi, which is given by:

$$
\begin{array}{r}
\operatorname{Pr}\left(z_{i}=1\right)=p_{i}=P_{r}\left(y_{f i}=1 \text { and } y_{e i}=1\right)=F\left(X_{i} \beta_{f}, X_{i} \beta_{e}, \rho\right) \\
\operatorname{Pr}\left(z_{i}=0\right)=1-p_{i}=\operatorname{Pr}\left(y_{f i}=0 \text { and } / \text { or } y_{e i}=0\right)=1-F\left(X_{i} \beta_{f}, X_{i} \beta_{e}, \rho\right)
\end{array}
$$

If parameters $\beta_{f}$ and $\beta_{e}$ are identified, we may estimate the four different probabilities regarding the four possible combinations of decisions made by the firm and by the employee, using reduced-form equations. A sufficient condition for local identification is that the information matrix of the log-likelihood function above is non-singular (Rothenberg, 1971). This condition, however, does not guarantee global identification.

The solution employed to deal with the lack of global identification was to make two estimations: one that supposed full observability and another one that 
assumed the partial observability described above. In case of full observability, two additional suppositions were necessary to estimate the model: (i) that the answers given by unemployed individuals about the dismissal initiative are perfectly true and (ii) that when one of the parties decides to end the employment relationship, the other party would have wanted to maintain it. Given these suppositions, we never have the "fire/quit" combination.

The importance of estimating the model by supposing full observability is that the estimated coefficients could be used as initial values for the estimation of the partial observability model. This procedure facilitates the convergence of the partial observability model to the correct equilibrium point.

Another important aspect to be considered regarding partial observability is the loss of efficiency in the estimation. Meng and Schmidt (1985) present some simulation results that confirm the intuitive notion that the larger the proportion of values 1 assumed by variable $z$ in the sample, the lower the cost of partial observability in terms of loss of efficiency. Since, in our case, this corresponds to the proportion of employees that kept the same job for one year, it is encouraging to note that this proportion is relatively high in our sample.

\section{Data}

The sample consists of data obtained at the individual worker level by the Employment and Unemployment Survey (PED). PED has been carried out every month by the SEADE and DIEESE foundations, since 1984. These databases are used to construct a monthly unemployment rate, among other aggregate indicators. Information from January 1985 to December 1999 are available. Every month, approximately 3,000 randomly selected families are interviewed in the metropolitan region of São Paulo (RMSP). Each individual is interviewed only once, differently from the rotating panel design that characterizes the PME/IBGE survey. However, PED has a great advantage over the PME: it contains information about job tenure, both about those workers who were employed at the moment of the interview and about the previous job for those who were unemployed at the time of the interview.

The information about the previous job tenure of those who were unemployed at the time of the interview is only available from February 1988 onwards. For this reason, the econometric estimations cover the period from February 1988 to December 1999.

The sample used in this study consists of individuals who, at the time of the interview, were employed in the same firm for at least one year, also including the individuals who had been unemployed for less than one year at the time of the interview. Individuals aged less than 10 years, domestic and public sector workers were excluded from the original sample.

Considering the whole sample, we observe that approximately $90 \%$ of workers were employed. The $10 \%$ unemployment rate in our sample underestimates the 
mean rate for the analyzed period. This is explained by the fact that the selected sample included only workers who had been unemployed for less than one year.

The mean age in the sample is 33 years, $64 \%$ are males, $48 \%$ are household heads, approximately $40 \%$ are formal employees (with a job contract) and the average worker completed 4 years of formal education. ${ }^{3}$

As expected, the number of terminated employment relationships observed every year tends to be larger in periods in which the unemployment rate rises (table 1).

Table 1

\begin{tabular}{cccc}
\hline YEAR & $\begin{array}{c}\text { Evolution of the } \\
\text { total number of } \\
\text { terminated } \\
\text { employment } \\
\text { relationships }\left(^{*}\right)\end{array}$ & $\begin{array}{c}\text { Open } \\
\text { unemployment } \\
\text { rate }\end{array}$ & $\begin{array}{c}\text { Variation of the } \\
\text { open } \\
\text { unymployment } \\
\text { rate }\end{array}$ \\
\hline 1988 & 2,930 & & \\
1989 & 2,683 & 7.02 & $-6.1 \%$ \\
1990 & 3,901 & 7.21 & $9.4 \%$ \\
1991 & 4,545 & 7.92 & $9.8 \%$ \\
1992 & 4,436 & 9.13 & $15.3 \%$ \\
1993 & 3,677 & 8.68 & $-4.9 \%$ \\
1994 & 3,353 & 8.92 & $2.8 \%$ \\
1995 & 3,819 & 8.95 & $0.3 \%$ \\
1996 & 3,805 & 9.93 & $10.95 \%$ \\
1997 & 4,309 & 10.16 & $2.32 \%$ \\
1998 & 4,599 & 11.67 & $14.9 \%$ \\
1999 & 2,576 & 12.06 & $3.3 \%$ \\
\hline
\end{tabular}

Source: PED/SEADE-DIESE

$\left(^{*}\right) 1$ - The number of terminated employment relationships observed every year does not correspond to the total number of terminated employment relationships associated with the interviewed workers, since, for every interviewed worker, we observe at most one terminated employment relationship every year. 2 - the sample size of PED did not change over the study period.

In addition, table 2 shows the evolution of the number of quits (\%) relatively to the total number of employment relationships terminated every year. This percentage tends to be larger in the years in which the level of employment in the metropolitan region of São Paulo was relatively higher.

\footnotetext{
${ }^{3}$ One should underscore that the information available from PED regarding the years of formal study is incomplete. The maximum number of study years corresponds to nine, and it is associated with all those who finished high school, also including those with a college degree. So, it is not possible to distinguish between those who finished high school and have a college degree from those who do not have it.
} 
Table 2

\begin{tabular}{ccc}
\hline YEAR & $\begin{array}{c}\text { Quits/total number of } \\
\text { terminated employment } \\
\text { relationships }\end{array}$ & $\begin{array}{c}\text { Percentage of employed } \\
\text { workers in PEA } \\
\text { (economically active } \\
\text { population) in the RMSP }\end{array}$ \\
\hline 1988 & $45 \%$ & 93.0 \\
1989 & $47 \%$ & 93.4 \\
1990 & $35 \%$ & 92.8 \\
1991 & $35 \%$ & 92.1 \\
1992 & $32 \%$ & 90.9 \\
1993 & $34 \%$ & 91.3 \\
1994 & $35 \%$ & 91.1 \\
1995 & $31 \%$ & 91.1 \\
1996 & $27 \%$ & 90.1 \\
1997 & $26 \%$ & 89.8 \\
1998 & $24 \%$ & 88.3 \\
1999 & $21 \%$ & 87.9 \\
\hline
\end{tabular}

Table 2 shows a clearly positive relation between the proportion of quits every year (relatively to the total number of terminated employment relationships) and the level of employment in the RMSP. In the analyzed period, the level of employment in the RMSP fell nearly continuously. More precisely, this level: (i) was quite high until 1989; (ii) fell until 1992; (iii) slightly increased in 1993, being stable until 1995; and finally, (iv) fell again until 1999. The proportion of quits follows the same tendency.

\section{Covariates}

Before discussing the explanatory variables used for the estimations, we should underscore that one of the major determinants for the possible termination of an employment relationship is the amount of specific training offered to the worker - defined as the type of training that increases the worker's productivity only in the firm where the training took place. This relation was originally pointed out by Becker (1962), who drew attention to the fact that the investment costs and returns regarding specific training should be shared between the employee and the employer so as to guarantee the continuity of the employment relationship for both parties. ${ }^{4}$ Becker concluded that there is an inverse relation between investment in specific training and the probability of termination of an employment relationship.

\footnotetext{
${ }^{4}$ However, such cost sharing is not simple, so experts in institutional economy developed theories about contract and organizational arrangements that resulted from the necessity of sharing costs. Given the difficulty in establishing this kind of arrangement, part of the literature assumes that specific training is exclusively paid by the firm - especially the literature whose focus lies on the effects of fixed labor costs on labor demand.
} 
Subsequent empirical studies showed that there is a positive correlation between general and specific training. ${ }^{5}$ This produces significant differences among firms regarding the average probability of termination of employment relationships, since firms use different technologies of production, which are quite distinct in terms of the average amount of training required from workers. However, the database used in this study contains scarce information about the firms.

The solution was to divide the sample into five sectors - making five separate estimations. ${ }^{6}$ The different sectors of economic activity differ in terms of the adopted technologies of production, which, in their turn, make them different in relation to the average firm size, to the average amount of training required from workers, and to the average specificity of skills required from workers. The division of the sample into five sectors allows the characteristics of the firms to be more homogeneous in the subsamples. ${ }^{7}$

Sector 1 includes large industrial companies characterized by a more intensive use of capital. ${ }^{8}$ Sector 2 includes smaller and less capital-intensive industries (textile sector, furniture sector, etc...). Finally, sectors 3, 4 and 5 correspond respectively to civil construction, commerce and services.

Table 3 shows the differences between these five sectors regarding the average job tenure and the percentage of workers with a formal job contract. ${ }^{9}$

\footnotetext{
${ }^{5}$ General training is defined as that which increases the worker's productivity not only in the firm where the training is offered but also in other firms. For Becker, this type of training should be paid by the worker. Mincer (1988) conducted an empirical study whose results indicate a negative effect of on-the-job training on turnover. For the author, this result may be explained by the positive correlation between general and specific components of on-the-job training.

${ }^{6}$ An estimate regarding the whole sample was not included because the intercept dummy variables are not enough to capture important differences between the sectors in the estimated parameters. The only reason to include this estimation is the efficiency gain from the increase in sample size, but this is not relevant in this study, given the size of the samples corresponding to the sectors.

${ }^{7} \mathrm{~A}$ vast literature exists on how the characteristics of jobs and firms influence labor turnoverincluding not only orthodox models, but also the developments of heterodox economic theory. Econometric studies that assess the relationship between labor turnover and the characteristics of the firms - such as size, technological sophistication and unionization - are quite common. This section does not deal with this issue in detail, due to the paucity of satisfactory data to analyze it empirically.

${ }^{8}$ According to the classification presented by Carvalho and Feijó (1993), the following sectors of processing industry are characterized by the presence of large companies, which offer attractive career opportunities to their employees: metallurgy, transportation materials, paper and cardboard, rubber, chemicals, pharmaceuticals, perfumery beverages and editorial and printing. Orellano (1997) used this classification to test the determinants for quits and dismissals and concluded that workers in these sectors have a lower chance to quit their jobs, even if other relevant factors, such as education, qualification level and formal job contract, are controlled.

${ }^{9}$ Note that the samples corresponding to each sector contain individuals who were employed in the sector at the time of the interview and individuals who had worked in the sector one year prior to the interview. Thus, the average job tenure calculated for each sector includes the average length of terminated employment relationships.
} 
Table 3

\begin{tabular}{lccccc}
\hline & $\begin{array}{c}\text { More capital- } \\
\text { intensive } \\
\text { industry }\end{array}$ & $\begin{array}{c}\text { Other } \\
\text { industrial } \\
\text { sectors }\end{array}$ & $\begin{array}{c}\text { Civil } \\
\text { construction }\end{array}$ & Commerce & Services \\
\hline $\begin{array}{l}\text { Average job } \\
\text { tenure }\end{array}$ & 5.3 years & 4.2 years & 3.9 years & 4, years & 4.9 years \\
\hline $\begin{array}{l}\text { \% of workers } \\
\text { with a formal } \\
\text { job contract }\end{array}$ & $80.4 \%$ & $60.3 \%$ & $31.4 \%$ & $38.0 \%$ & $43.7 \%$ \\
\hline Source: PED/SEADE-DIESE & & & & & \\
\hline
\end{tabular}

Table 3 shows large differences between the five sectors regarding the percentage of workers with a formal job contract. Industry, in general, has a high level of formality concerning employment relationships, followed by the service, commerce and civil construction sectors. This difference may be due, to a great extent, to the fact that industrial firms are usually larger in comparison with firms belonging to other sectors, which allows these firms to be more easily monitored in terms of legal compliance.

Also important is the difference in the level of formality between the most capital-intensive industry and the other industrial firms, which supports the division of industries into two large subsectors, singling out the most capital-intensive industry. The latter one also has a clearly longer average job tenure. ${ }^{10}$ It is interesting to note that the less capital-intensive industry does not differ from the commerce and service sectors with regard to the average job tenure, despite the higher level of formality in employment relationships observed in the industry.

In all sectors, the two bivariate probit models (supposing full and partial observability) were estimated - and a set of covariates was included in all estimations. The covariates that indicate job characteristics are concerned with the job that is being analyzed, which we call "reference job." For individuals who were employed at the time of the interview, the "reference job" would be the job they held at that time. For unemployed individuals, the "reference job" would be the last job, which they left before the interview.

The set of covariates common to the five sectors, which will be discussed ahead, consists of: (i) a dummy variable using number 1 to indicate female workers (gender); (ii) a dummy variable using number 1 to indicate the household head (head); (iii) age (age); (iv) worker's tenure in the "reference job" (tenure); (v) level of formal education determined by the number of school years (educ) $)^{11}$; (vi) a dummy

\footnotetext{
${ }^{10}$ This observation is consistent with the result obtained by Orellano (1997), according to whom workers in the most capital-intensive sectors have a lower chance to quit their jobs, even if other factors, such as education, qualification level and formal job contract, are controlled.

${ }^{11}$ As mentioned in a previous note, one should recall that the maximum number of school years is nine, and that this number is associated with all those individuals who finished high school, including those with a college degree.
} 
variable using number 1 to indicate the workers who had a formal job contract in the "reference job" (contr.); (vii) open unemployment rate (PED/SEADEDIEESE) published in the month in which the worker left the job, or the mean open unemployment rate during the year in which the workers kept the same job (open_unemp); (viii) variation of (deseasonalized) sector GDP in the two months preceding the date on which the worker left the job, ${ }^{12}$ or the monthly average of the total sector GDP variation during one year, for workers who kept the same job (gdpvar); (ix) a dummy variable indicating the period after November 1988, when the new constitution made some changes to the Brazilian labor legislation, for workers with a formal job contract and at least three months in the job ( $\operatorname{ecc} 88$ ); and finally, (x) ten more dummy variables, one for each year, from 1990 to $1999 .{ }^{13}$

The discussion about the meaning and the expected effect of each of these covariates is clearer if they are divided into two groups. The first group consists of variables that indicate the workers' personal characteristics, or the specific characteristics of the employment relationship being analyzed. This group includes the first six covariates listed above. The other group, which includes all the remaining covariates, consists of variables that indicate changes in the "macroeconomic environment" (including changes in the legislation), or changes in the sector of economic activity analyzed.

Some empirical studies demonstrated that the probability of married men, especially those with children, quitting their jobs is lower than that for single men. ${ }^{14}$ The opposite occurs with women. Married women, especially those with children, have a higher probability of quitting their jobs, due to their sporadic absence from work to look after their children and their house. ${ }^{15}$ Therefore, the first two covariates included in the estimations seek to capture these effects, the first one indicating the worker's gender and the second one indicating the worker's position as "household head," a position that can also be taken by the woman.

The variable "age" is expected to have an inverse relation with the probability of quitting and being fired. The longer the participation in the labor market (which tends to increase with age), the longer the time this individual had to devote himself to looking for a job and, therefore, the higher his level of satisfaction

\footnotetext{
${ }^{12}$ In case of sectors 3, 4 and 5, only quarterly GDP data were found. Thus, for the first month of each quarter, we associated the GDP variation observed between the two previous quarters. For the last month of each quarter, we associated the GDP variation between the previous quarter and the quarter corresponding to this month. For the intermediate month, we associated the mean of these two variations.

${ }^{13}$ The dummy variable indicating a certain year (say, year $X$ ) was constructed in the following manner. Value 1 was associated with individuals who left their jobs in that year and with individuals who were interviewed in that year. The latter ones kept the same job at least for twelve months between the beginning of year $(X-1)$ and the end of year $X$.

${ }^{14}$ The study conducted by Mincer (1978) is an example. The author explains this result using the highest opportunity costs to change jobs resulting from family bonds. However, one may argue that married men are more averse to the risk of leaving a job only to look for another one.

${ }^{15}$ See Lynch (1992:18).
} 
should be. This should occur not only in terms of wage, as presented in the model developed by Burdett (1978), but also with regard to other job characteristics. Thus, the worker's age should have a positive correlation with the job matching quality, reducing the probability of quitting and the probability of being fired. On top of that, the older the individual, the lower the return expected from the job searching activity, which should also reduce the probability of quitting.

Job tenure is a way to measure the amount of specific skills acquired by an employee. In this case, the idea is simple: the longer a worker stays on the job, the more time he has to acquire these specific skills in relation to the firm where he works. As discussed at the beginning of this section, this should reduce the probability of quitting and the probability of being fired.

Another variable included to measure the amount of specific skills acquired by the worker is his level of formal education. As asserted by Mincer (1994:121), the human capital theory supposes that individuals who achieved a higher level of formal education tend to get a higher amount of on-the-job training - which explains the use of the level of formal education as a way to measure the amount of on-the-job training received by the worker. ${ }^{16}$ This theoretical result is based on the hypotheses of persistence of investment in human capital and complementarity of investment in human capital. The former supposes that individuals who invested more in formal education will also invest more in training, since the same individual factors that led them to make the first type of investment in human capital will also lead them to invest more in training. The second hypothesis posits that investment in formal education allows individuals to derive more benefits from on-the-job training.

Finally, as the last covariate that indicates specific characteristics of the employment relationship, we included the dummy variable indicating that the worker had a formal job contract (assuming value 1 for workers with a formal job contract). Obviously, we expect a negative effect of this variable on the probability of dismissal by the firm, since the formal employment relationship imposes additional dismissal costs (basically, termination notice and FGTS penalty).

Dismissal costs, as well as hiring costs and initial training costs, constitute the fixed costs (or "quasi-fixed costs") of the labor factor, as they are not proportional to the amount of working hours each employee will devote to the firm, although they are proportional to the number of hired employees. A vast literature exists on the effect of such costs on the dynamics of labor demand, but Oi (1962) was the one who developed this idea. Several models were later developed, ${ }^{17}$ reaching the same conclusion that fixed labor costs reduce the oscillation in labor demand

\footnotetext{
${ }^{16}$ The use of the level of formal education as a way to measure the amount of specific skills acquired by the worker requires the additional hypothesis that processes of job training always have some specificity with regard to the firm where they take place - which was discussed at the beginning of this section and is advocated by Doeringer and Piore (1971) and Mincer (1988).

${ }^{17}$ See Nickell (1978), Nickell (1986) and Nickell (1995).
} 
- reducing the volume of hirings in periods of growth and the volume of dismissals in periods of recession. Thus, these models suppose that higher dismissal costs imply lower probability of dismissal by the firms, as the employment relationships would be on average more stable in a context with higher costs.

A priori, we also expect an inverse relation between the variable formal job contract (which indicates the formal employment relationship) and the probability of quitting. The fact is that the formal employment relationship offers benefits to the worker (such as welfare, paid vacations, maternity leave, termination pay in case of unfair dismissal, among others). These advantages are highly valued by workers and, therefore, should reduce the probability of these workers quitting their jobs. This conclusion has already been confirmed by empirical tests. ${ }^{18}$

Now shifting to the group of variables that indicate changes in the "macroeconomic environment" or changes in the analyzed sector, the first one we have is open unemployment (open_unemp). The influence of this variable on the probability of quitting is formalized in job search models such as that by Barron and McCafferty (1977), which results in a function that determines the quit rates. According to this model, the level of labor demand is an exogenous variable that influences the individual decision of each worker to search for a job. The rise in labor demand increases the expected net return from the job search, then, the total number of quits responds positively to an increase in the level of labor demand and negatively to a reduction in this level. This generates an inverse relation between unemployment rate and the probability of quitting, which was corroborated in empirical studies such as that carried out by Mincer (1988). ${ }^{19}$

The unemployment rate can also be viewed as a relevant variable to the decisions of firms to fire employees, however, should have a positive relation with the probability of dismissal by the firm, contrary to what occurs with the probability of quitting. The idea is that the firm, when deciding to fire employees, observes the available information about economic activity. The higher the unemployment rate in the previous period, the higher the probability of dismissal by the firm should be.

At this point, it is important to note that the unemployment rate being associated with the workers who left their jobs (quit or fired) corresponds to the unemployment rate of the month prior to dismissal or quitting. Thus, the effect that is measured is that of the unemployment rate on the probability of firing, and not the other way round.

The variable gdpvar, in its turn, is used to measure the variation of product demand in each sector, since a decrease in the demand for a firm's product should

\footnotetext{
${ }^{18}$ See Orellano (1997:87).

${ }^{19}$ Mincer (1988) conducted an empirical study in which the unemployment rate is included as explanatory variable for the mobility of each worker between firms. Unemployment inhibits quitting because it reduces the probability of finding another job. According to the author, unemployment inhibits quits in a larger proportion than the increase in dismissals by the firms.
} 
generate an adjustment of production so that this production can restore the firm's equilibrium (profit maximization). By supposing that employers do not fire employees at the first sign of reduction in sales, seeking first to reduce production by reducing the number of hired working hours, the variable gdpvar is a way to measure the demand for the product in the previous period. Dismissals should occur only in a second moment, after an initial reduction in production - provided that the firm believes in the persistence of this decrease in the product demand.

The previous non-seasonal variation of production was used because the firms expect the seasonal decreases in the demand for the product, knowing that they are followed by recovery in the same year. Therefore, a seasonal decrease in demand should not cause dismissals - especially when the hiring and dismissal costs are significant for the firms. However, if a non-seasonal decrease in the demand for the product occurs and this decrease is seen as persistent, this may result in dismissals after a decrease in production.

As the variable gdpvar indicates previous (non-seasonal) variations in production, given the arguments presented in the two previous paragraphs, a reduction in this variable (assuming sometimes negative values) is expected to increase the probability of dismissal by the firms.

The inclusion of the variable gdpvar as explanatory variable for the probability of quitting, follows a logic that is quite close to that used to explain the relationship between unemployment and quitting. According to the hypotheses being used, previous (non-seasonal) increases in the product of a sector may imply hirings in the subsequent period. This may especially increase the probability of quits among employees in this same sector-- who have already acquired skills which, even if not specific to the firm where they have worked, may be specific to the sector of economic activity.

Getting on with the analysis of covariates that indicate changes in the macroeconomic environment, we should now discuss the expected effect of the variable dec88, which indicates the period after November 1988 (date on which changes were made to labor legislations by the new constitution) for those workers with a formal job contract and with at least three months on the job. ${ }^{20}$

The incentive mechanism produced by the Brazilian employment protection legislation is quite complex. For that reason, the potential effects caused by a change in this legislation are often contradictory.

With the new Brazilian constitution, the FGTS penalty charge, which should be compulsorily paid by the firms when they dismiss an employee without good reason, increased from $10 \%$ to $40 \%$. Given this increase in the dismissal cost, this change is expected to have lowered the probability of dismissal by the firm for those workers with a formal job contract (and at least three months on the job). On the other hand, the fact that the worker can withdraw the money paid by

\footnotetext{
${ }^{20}$ Only the employees with at least three months in the job are entitled to indemnity for dismissal without grounds, as the first three months in the job are regarded as probation period.
} 
the firm may represent an incentive for him to force his own dismissal, especially in periods of economic growth. Dismissal would be formally seen as dismissal without good reason, when, actually, the worker has the intention to leave the job. The increase in the FGTS penalty charge to be paid by the firm would therefore encourage workers to leave the job.

However, there is one factor that makes this incentive mechanism even more complex: the worker has the right to withdraw the balance of the FGTS account when he is fired. That is, dismissal by the firm implies that the worker is entitled to withdraw the balance of the FGTS account plus the penalty charge paid by the firm. So, there exists the possibility that the firm and the worker will make an agreement in cases in which the worker intends to leave the job. In this agreement, the firm accepts to fire the worker without good reason so that he can withdraw the balance of his FGTS account, but the worker would have to give the amount corresponding to the penalty charge back to the firm.

The increase in the FGTS penalty charge may have inhibited such agreements, since the short-term gain earned by the worker in cases of agreement is reduced with the increase in the FGTS penalty charge. In addition, the employer may feel more reluctant to accept these agreements, since there is an increased risk of the worker not returning the penalty charge paid by the firm. Given all these factors, it is difficult to accurately predict the effect of the increase of the penalty charge on the decision of workers to leave the job.

There is still another relevant change implemented by the new constitution: the creation of the unemployment insurance for workers with a formal job contract. According to the literature, this change encourages attitudes that lead to dismissal by the firm, in periods of low unemployment rate. However, this effect cannot be considered a consensus among researchers, neither from the theoretical nor from the empirical point of view.

Finally, to conclude the discussion about the set of covariates common to all estimations, we have to explain the inclusion of dummy variables associated with each year in the 1990-1999 period. These "year dummies" aim to control the possible effects produced by other relevant macroeconomic changes, as the Brazilian economy had important changes in the 1990-1999 period, such as stabilization plans and the process of trade liberalization.

Only the estimations relative to the two industrial sectors include an additional covariate - in addition to the set of covariates common to all estimations, as previously mentioned and discussed. This covariate, herein referred to as volatile, seeks to capture the level of uncertainty in relation to the future in each time period. It is an indicator that measures the volatility of the level of production in each period, which was constructed from the data on production available from FIESP, Federation of Industries of the State of São Paulo, based on a GARCH model.

The expected relation between this covariate and the probabilities of quit and 
dismissal results from the hypothesis that a greater uncertainty in relation to the future (the volatility of the level of production is considered an indicator of uncertainty), reduces the response of firms to the previous changes observed in the product demand. In other words, in a moment of higher volatility, an economic setback should not cause several dismissals in the subsequent period, since firms do not view this setback as permanent (or long-lasting). On top of that, one may argue that, in periods of greater uncertainty, a previous economic expansion does not result in hirings in the subsequent period- thus not inducing quits due to a more fierce competition for labor among firms. Therefore, the volatile variable is expected to reduce quits and dismissals by the firm.

It is worth noticing that, as will be discussed in the next section, the volatility of production in industry increased significantly after 1994 (in addition to being high in 1990). This increase also corresponds to a change in economy in the 1990s, whose effect will be tested.

The volatile variable was only included in the two industrial sectors for two reasons. One reason is that this measure of production volatility was constructed based on data about the industry provided by FIESP. The second reason is that, in industry, turnover costs for the firms tend to be larger, given the increased costs with training. This makes firms hesitate more before they decide to dismiss employees. Therefore, even with a decrease in the product demand, they can try to avoid dismissal in situations of uncertainty.

\section{Estimation results}

Table 4, on next page, contains a summary of the estimated coefficients for the covariates included in all estimations - with regard to the bivariate probit model with partial observability. ${ }^{21}$ It should be highlighted that a coefficient with a positive sign, for instance, indicates that the covariate reduces the probability of dismissal. This occurs because the dependent variable has to be constructed in such a way that number 1 is associated with those workers who did not leave their jobs during one year of observation.

\footnotetext{
${ }^{21}$ The coefficients estimated using the bivariate probit model with full observability are shown in table A.1, in the statistical appendix at the end of this paper. The coefficients estimated by this model were used as initial values for the estimation of the partial observability model.
} 
Table 4

Bivariate probit model with partial observability estimated coefficients, $\left({ }^{*}\right)$ for the set of covariates common to five estimations

\begin{tabular}{|c|c|c|c|c|c|}
\hline $\begin{array}{c}\text { fire } \\
\text { equation }\end{array}$ & Sector 1 & Sector 2 & Sector 3 & Sector 4 & Sector 5 \\
\hline gender (fem) & $\mathrm{NS}$ & $\mathrm{NS}$ & -0.142 & -0.051 & $\mathrm{NS}$ \\
\hline Head & NS & NS & 0.205 & 0.083 & 0.074 \\
\hline Age & 0.014 & 0.023 & 0.006 & 0.024 & 0.022 \\
\hline Educ & 0.065 & 0.072 & 0.026 & 0.012 & 0.087 \\
\hline Tenure & 0.004 & 0.010 & 0.003 & 0.003 & 0.010 \\
\hline Contr. & -1.953 & -1.056 & 0.939 & 0.823 & 0.428 \\
\hline Open_unemp & -18.671 & -13.540 & -0.651 & -0.708 & -3.831 \\
\hline gdpvar & 60.646 & 48.761 & 2.254 & -0.299 & 167.399 \\
\hline dec 88 & 3.438 & 2.587 & NS & NS & 0.696 \\
\hline dum90 & -7.228 & -6.062 & -0.356 & -0.194 & 0.602 \\
\hline dum91 & 13.106 & 9.061 & 0.225 & 0.536 & 3.130 \\
\hline dum92 & 33.996 & 24.596 & 0.767 & 1.382 & 7.238 \\
\hline dum93 & 39.890 & 29.271 & 1.163 & 1.392 & 8.486 \\
\hline dum94 & 29.709 & 21.331 & 1.036 & 1.310 & 7.065 \\
\hline dum95 & 29.238 & 20.727 & 1.030 & 1.278 & 7.597 \\
\hline dum96 & 47.449 & 33.331 & 1.332 & 1.751 & 9.765 \\
\hline dum97 & 51.846 & 36.415 & 1.635 & 2.023 & 10.915 \\
\hline dum98 & 77.493 & 55.559 & 2.325 & 2.777 & 16.378 \\
\hline dum99 & 87.678 & 61.469 & 3.000 & 3.708 & 19.199 \\
\hline Constant & 130.871 & 93.818 & 5.436 & 5.439 & 26.088 \\
\hline $\begin{array}{c}\text { quit } \\
\text { equation }\end{array}$ & Sector 1 & Sector 2 & Sector 3 & Sector 4 & Sector 5 \\
\hline gender (fem) & $-0.059\left(^{* *}\right)$ & NS & $\mathrm{NS}$ & $\mathrm{NS}$ & $\mathrm{NS}$ \\
\hline Head & $\mathrm{NS}$ & NS & 0.312 & NS & 0.115 \\
\hline Age & 0.015 & 0.025 & NS & 0.025 & 0.021 \\
\hline Educ & 0.077 & 0.093 & NS & NS & 0.087 \\
\hline Tenure & 0.007 & 0.012 & 1.619 & 4.839 & 0.010 \\
\hline Contr. & 2.408 & 1.873 & NS & NS & 0.771 \\
\hline Open_unemp & 2.318 & 2.573 & 1.642 & 5.015 & 8.505 \\
\hline gdpvar & -6.234 & -18.372 & -4.480 & -0.533 & -493.311 \\
\hline $\operatorname{dec} 88$ & -0.743 & -0.404 & NS & NS & 0.364 \\
\hline dum90 & 0.835 & 0.600 & 0.176 & 2.351 & -0.460 \\
\hline dum91 & -1.494 & -2.242 & -1.949 & -4.094 & -10.255 \\
\hline dum92 & -3.037 & -3.642 & -2.498 & -6.554 & -12.147 \\
\hline dum93 & -4.681 & -5.514 & -4.097 & -11.552 & -21.218 \\
\hline dum94 & -4.012 & -4.852 & -3.445 & -10.965 & -20.026 \\
\hline dum95 & -3.806 & -4.780 & -3.813 & -11.540 & -19.458 \\
\hline dum96 & -5.383 & -6.463 & -4.634 & -12.220 & -25.162 \\
\hline dum97 & -6.356 & -7.215 & -5.654 & -17.250 & -27.727 \\
\hline dum98 & -8.538 & -10.071 & -6.656 & -18.070 & -34.132 \\
\hline dum99 & -10.758 & -12.696 & -8.929 & -26.138 & -46.737 \\
\hline Constant & -16.286 & -18.084 & -29.236 & -90.124 & -51.680 \\
\hline Wald test & 8600.130 & 8311.13 & 1485.86 & 4236.43 & 22249.94 \\
\hline Log likelihood & -7171.604 & -7493.78 & -4977.746 & -12596.577 & -19614.812 \\
\hline
\end{tabular}

As was done in the previous section, when the meaning and expected effect of each covariate were discussed, the results will be presented by dividing the covariates into two groups- those that indicate characteristics of the individuals or of the employment relationship; and those that indicate changes in the macroeconomic environment or in the analyzed sector.

Starting with the first group, the variable tenure (which indicates the length 
of the employment relationship for the "reference job") had a significant effect, with the expected sign, on all estimations. That is, the longer job tenure reduces the probabilities of quitting or being fired, in all analyzed sectors. This result corroborates that one obtained by Orellano (1997:82), suggesting that, in fact, the longer job tenure results in a larger amount of specific skills, encouraging both parties to keep the relationship stable.

The worker's formal level of education, measured by variable educ, as described in the previous section, is also pointed by the theory as an indicator of the amount of specific training received by the worker (in addition to variable tenure), and should therefore reduce the probabilities of quitting and being fired. The estimations confirm the hypothesis of reduction in quits for the two industrial sectors and for the service sector. The higher level of formal education of a worker certainly reduces the probability of dismissal by the firm, since the obtained results show that this inverse relationship is significant for all sectors.

The significance of variable educ in fire equations indicates that the costs incurred by the firms for adjusting the demand for labor - as expected - increase with the level of education of the employees. The specific training costs correspond to part of these adjustment costs that should be shared with the employees. Since variable $e d u c$, in the civil construction and commerce sectors, is not significant in quit equations, this suggests low costs with specific training in these sectors, or the inability of firms to share the costs of this training with the employees, avoiding unwanted dismissals - or a low correlation between level of education and specific training.

The variable contr., which is the last variable to indicate a specific characteristic of the employment relationship, had the expected effect on the probability of dismissal by the firm, only in non-industrial sectors. That is, the formal employment relationship reduces the probability of dismissal by the firm, as expected, only in non-industrial sectors. Curiously enough, the opposite occurs in industrial sectors.

On top of that, the variable contr had the expected (significant) effect on the probability of quitting in the two industrial sectors and in the service sector. In these sectors, the formal employment relationship reduces the probability of quitting, even when other characteristics of the employment relationship are controlled. This indicates that the benefits obtained by the worker with the establishment of a formal relationship (including the relatively higher job stability) are in fact valued by the worker, reducing his propensity for quitting. In the civil construction and commerce sectors, according to the estimation made, the variable contr has no significant effect on the probability of quitting.

The last three covariates of the first group that was initially mentioned (which indicate characteristics of the individual or of the employment relationship) correspond to the workers' personal characteristics: gender, head and age. The variable age had the expected significant effect in all fire equations, also having the expected 
(significant) effect in the quit equation in four sectors - the only exception was the civil construction sector. For the reasons discussed in the third section, the more advanced age of a worker is expected to reduce his probability to quit the job, regardless of the correlation between age and job tenure. The probability of dismissal by the firm should also be lower. Both hypotheses were confirmed by the results of the tests.

Differently from the variable age, the variable dummy which indicates female individuals did not have a significant effect on the probability of dismissal (quitting or firing). The only two exceptions were the fire equations of the civil construction and commerce sectors. In these sectors, the results indicate that women have a higher probability to be dismissed by the firms.

Finally, the variable head, which indicates the household heads, did not show a significant effect on the probability of dismissal in several sectors. Being a household head reduces the probability of dismissal by the firm in the civil construction, commerce and service sectors, but this does not occur in the industry. Moreover, the results show that being the household head only has the significant effect of reducing the probability of quitting in the civil construction and service sectors.

So, we move on to the analysis of the second group of covariates - which indicate changes in the macroeconomic environment or in the analyzed sector. Here, the first observation is that the unemployment rate had the expected (significant) effect on all estimations. That is, in the five analyzed sectors, a higher unemployment rate, observed in the period prior to the termination of an employment relationship, increases the probability of dismissal by the firm and reduces the probability of quitting on the worker's side.

The previous sectoral GDP variation (seasonally adjusted) also had the expected effect. The only exception is the fire equation of the commerce sector. In other cases, a positive previous variation of production had the expected (significant) effect of reducing the probability of dismissal by the firm and increasing the probability of quitting.

Therefore, among the set of covariates included in all estimations, now we only have to analyze the effects of the dummy variables (those which indicate the change in labor legislation and the "year dummies").

The variable $\operatorname{dec} 88$, which indicates the moment of change in the Brazilian labor legislation, had the expected effect of reducing the probability of dismissal by the firm in three sectors, not having a significant effect only in the civil construction and commerce sectors. The effect of this variable on the probability of quitting is not consistent among sectors. The probability of quitting, after the changes in the labor legislation, increases in industry, but decreases in the service sector, not having a significant change in other sectors.

These results - especially those concerning the impact of the new constitution on the probability of dismissal by the firm - are in accordance with what was expected. Even so, they should be looked at with caution, as the fact that the 
data are available only from February 1988 onwards may have limited the analysis, given the possibility that there might have been an anticipation of the changes in the legislation by the agents. Gonzaga (2003) analyzed the 1982-2002 period using a difference-in-difference methodology and concluded that the increase in dismissal cost reduced labor turnover. Furthermore, he concluded that the increase in the FGTS penalty charge reduced the probability of agreements - in which the initiative of dismissal is taken by the worker, but is formally registered as dismissal by the firm.

When analyzing the "year dummies," it should be noted that the dummies relative to the 1991-1999 period had significant and consistent effects in all analyzed sectors. One may also observe that in 1990 the probability of dismissal by the firm was relatively higher in four of the analyzed sectors - which is not surprising, given the extremely restrictive adjustment policy implemented. In that year, as expected, the probability of quitting was relatively lower in the same four sectors. The only exception was the service sector.

From 1991 onwards, the probability of dismissal by the firm begins to be relatively lower in all sectors, given the control over the unemployment rate - this effect is increasingly stronger after 1995. We may say that the reduction in the probability of dismissal by the firm increases from 1995 on because there is an evident increase in the absolute values of coefficients estimated from 1995 in all sectors.

A possible interpretation for this result could be the firms' modernization process - with the adoption of new technologies of production - which most researchers believe occurred in the 1990s due to the trade liberalization. However, the literature on the relationship between technology of production and labor turnover assumes that technological modernization should also reduce the probability of quitting. Nevertheless, this is not what "year dummies" indicate in quit equations. They show an increase in the probability of quitting in the 1991-1999 period, with other factors being controlled.

Another possible interpretation of the result obtained lies in the fact that unemployment is not a good indicator of aggregate demand for the 1990s. The table below shows the evolution of the GDP variation rate in São Paulo and of the open unemployment rate in the Metropolitan Region of São Paulo for the 1991-1999 period. 
Table 5

\begin{tabular}{lccc}
\hline Year & GDP $\left(^{*}\right)$ & $\begin{array}{c}\text { GDP variation rate in } \\
\text { São Paulo }\end{array}$ & $\begin{array}{c}\text { Open unemployment rate in } \\
\text { the Metropolitan Region of } \\
\text { São Paulo }\left(^{* *}\right)\end{array}$ \\
\hline 1991 & 100,14 & & 7,917 \\
1992 & 95,99 & $-4,14 \%$ & 9,133 \\
1993 & 103,97 & $8,31 \%$ & 8,683 \\
1994 & 111,20 & $6,95 \%$ & 8,925 \\
1995 & 113,42 & $2,00 \%$ & 8,950 \\
1996 & 115,84 & $2,13 \%$ & 9,933 \\
1997 & 119,49 & $3,15 \%$ & 10,158 \\
1998 & 115,47 & $-3,36 \%$ & 11,667 \\
1999 & 110.22 & $-4,55 \%$ & 12,058 \\
\hline$\left.{ }^{*}\right)$ Source $=$ FIPE macrodata & \\
${ }^{* *}$ Source $=$ PED/SEADE-DIEESE
\end{tabular}

Between 1991 and 1993, the GDP oscillates, decreasing and increasing, then continuously increasing until 1997. The open unemployment rate - unlike the GDP, as would be expected -, increases and drops again between 1991 and 1993 . However, despite the (modest) GDP increase in the 1993-1997 period, we observe an increase in the unemployment rate throughout these years.

As mentioned in the third section, the use of the open unemployment rate as one of the variables that can explain the probability of dismissal by the firms presupposes that the unemployment rate of a given period provides employers with information about the level of economic expansion. This information would be used by firms in the subsequent period as a way to decide whether they should hire or fire employees. In fact, as previously seen, the results confirm that the open unemployment rate of a certain period increases the probability of dismissal by the firm in the subsequent period. Nevertheless, as the unemployment rate rises even in the presence of GDP growth, the dismissal by the firm should actually be less probable. This may be an explanation to the increasing reduction in the probability of dismissal by the firm observed in the "year dummies" after 1995.

Differently from what occurs with the positive relationship between unemployment and the rate of dismissal by the firms, the expected inverse relation between unemployment and quit rates does not result from the hypothesis that unemployment is an indicator of aggregate demand. The variable that really matters when workers have to decide whether to quit or not is the unemployment rate. Thus, theory posits that the growing increase in the unemployment rate throughout the 1990s should reduce the probability of quitting - which was confirmed by the results obtained with the estimates.

However, given the results obtained for the "year dummies," the estimations suggest that the reduction in quit rates, throughout the 1990s, was not so remarkable as expected, given the increase in unemployment. In other words, the quit 
rates in the 1990s did not respond negatively to the increase in the unemployment rate in a linear way.

Finally, with regard to the volatile variable, which was not included in all estimations, the results are presented in the statistical appendix at the end of this paper. As expected, this variable reduced the probability of dismissal by the firm in two industrial sectors. Thus, the results suggest that in moments of uncertainty the firms do not respond immediately to a reduction in sales with layoffs, instead, they tend to reduce the number of working hours as a way to decrease production until economic stability can offer reasonable certainty about the future.

The effect of the volatile variable on the probability of quitting was not significant in less capital-intensive sectors of the industry, being contrary to that which was expected for the capital-intensive industry, since the increase in the production volatility increases the probability of quitting.

Note that the volatile variable showed a strong upward trend in the 1990s, as shown in the following graph. 


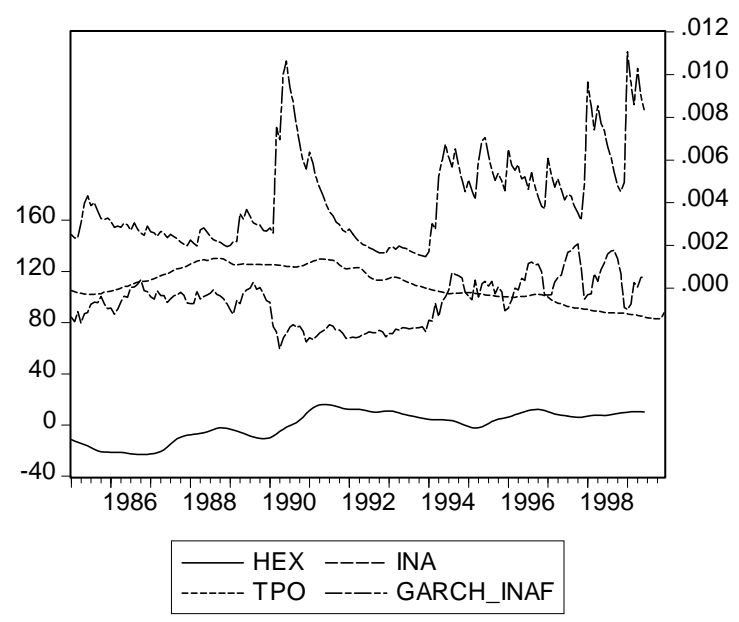

Figure 1

Production volatility in the industry of São Paulo (1985-2000)

In this graph, constructed with data from FIESP, the variable TPO represents the number of employees carrying out production work and the variable INA represents an indicator of the level of activity of São Paulo's industries. From 1994 onwards, there is a growing level of activity (with strong oscillations) and a decrease in the total number of employees in production work. ${ }^{22}$ The variable HEX, which indicates the number of extra working hours worked in production, shows an upward trend, and so does the level of activity. The variable GARCH-INAF corresponds to the volatile variable used for the estimations in this paper. Note that, from 1994 on, industrial production volatility has a relatively higher and more unstable level, especially if compared with the 1991-1993 period.

\section{Conclusions}

In this study, the analysis of the determinants of dismissals and quits revealed some patterns common to most or all sectors analyzed. These patterns may be observed more clearly in table 4 , in the previous section.

Beginning with workers' personal characteristics, age and level of formal education showed clear and consistent effects. Age strongly reduces the probability of dismissal and also reduces the probability of quitting in four of the five analyzed sectors. A similar behavior is observed for the level of formal education, thus

\footnotetext{
${ }^{22}$ These data show that increases in the level of production were not followed by an increase in labor demand, due to the decrease in the number of employees working in production. The increase in production seems to result from the increase in the number of extra hours worked.
} 
indicating higher costs for the firm with the hiring and firing of employees who have a better level of education. Moreover, as a higher level of formal education substantially reduces the probability of quitting in the industry and in the service sector, the results suggest that in these sectors the costs with specific training are positively correlated with the level of formal education.

As for the characteristics of each employment relationship, the results obtained show that job tenure reduces the probability of quitting and the probability of dismissal by the firm, in all analyzed sectors. This strongly suggests that the acquisition of specific skills by the worker induces longer employment relationships and greater loyalty from both sides.

It was also observed that a formal employment relationship reduces the probability of quitting, as expected. However, the establishment of a formal employment relationship only reduces the probability of dismissal by the firm in non-industrial sectors, having the opposite effect on the industry, differently from what one would expect.

By analyzing the effects of the variables that indicate changes in the macroeconomic environment, we noted that the marginal effect of the open unemployment rate in the five sectors analyzed was consistent with the theories about dismissal and quit determinants. In other words, the unemployment rate of a given period has a negative effect on the probability of quitting and a positive effect on the probability of dismissal by the firm in the subsequent period.

Nonetheless, the results suggest that the increase in the unemployment rate observed in the 1990s had an increasingly weaker effect on the rate of dismissals by the firms. In addition, the quit rates in the 1990s did not respond negatively to the increase in the unemployment rate in a linear way.

The changes to the Brazilian labor legislations made in November 1988 reduced the probability of dismissal by the firm, as expected, not showing a significant effect only in the civil construction and commerce sectors. This result corroborates the conclusions reached by Gonzaga (2003) who, after using the differences-indifferences methodology, concluded that the increase in dismissal costs decreased labor turnover. On the other hand, following our results, the effect of the change in legislation on the probability of quitting is not consistent across sectors.

These results about the effects of institutional changes should be carefully weighted, because the data began to be collected in February 1988, which may limit the analysis, given the possible anticipation of institutional changes by the agents.

Finally, we conclude that an increase in industrial production volatility as a whole, which may be considered a way to measure uncertainty about the future, reduces the responses of industrial firms (dismissals) to variations in the economic activity.

Our results do not allow us to conclude that the changes in production technology in the 1990s reduced labor turnover - which would be expected in case 
of technological improvement. This is, however, an issue that should be further investigated.

\section{References}

Amadeo, E. J., Barros, R. P., Camargo, J. M., Mendonça, R., Pero, V., \& Urani, A. (1993). Ajuste estrutural e flexibilidade do mercado de trabalho no Brasil. Anais da Anpec, 2:503-531.

Baltar, P. E. \& Proni, M. W. (1995). Flexibilidade do trabalho, emprego e estrutura salarial no Brasil. Cadernos do CESIT, Texto para Discussão 15, Unicamp, Campinas, SP.

Barron, J. M. \& McCafferty, S. (1977). Job search, labor supply, and the quit decision: Theory and evidence. The American Economic Review, 67(4):683691.

Barros, R. P., Corseuil, C. H., \& Bahia, M. (1999a). Labor market regulations and the duration of employment in brazil. Instituto de Pesquisa Econômica Aplicada - IPEA, Texto para Discussão Interna 676, Rio de Janeiro.

Barros, R. P., Corseuil, C. H., \& Foguel, M. N. (2001). Os incentivos adversos e a focalização dos programas de proteção ao trabalhador no Brasil. IPEA, Texto Para Discussão Interna, 784, Rio de Janeiro.

Barros, R. P., Corseuil, C. H., \& Gonzaga, G. (1999b). Labor market regulations and the demand for labor in Brazil. IPEA, Texto para discussão Interna, 656, Rio de Janeiro.

Beaudry, P. (1994). Entry wages signaling the credibility of future wages: A reinterpretation of the turnover-efficiency-wage model. Canadian Journal of Economics, XXVII(4):884-902.

Becker, G. S. (1962). Investment in human capital: A theoretical analysis. Journal of Political Economy, pages 9-49.

Becker, G. S. (1964). Human capital: A theoretical and empirical analysis, with special reference to education. Columbia University Press, New York.

Burdett, K. (1978). A theory of employee job search and quit rates. The American Economic Review, 68(1):212-220.

Cacciamali, M. C. (1992). Mudanças estruturais e na regulação do mercado de trabalho no Brasil nos anos 80. Texto para Discussão Interna, 6, IPE/USP.

Carvalho, P. G. M. \& Feijó, C. A. V. (1993). Rotatividade do pessoal ocupado na indústria: Sua evolução nos anos recentes - 1985-1993. Anais da Associação Brasileira de Estudos do trabalho. 
Chahad, J. P. \& Fernandes, R. (2001). Unemployment insurance and transitions in the labor market: An evaluation of Brazil's program. Texto para Discussão, Série Economia, FEA-USP, Campus de Ribeirão Preto.

Chahad, J. P., Orellano, V. I. F., \& Picchetti, P. (2001). A bivariate probit analysis of quits and dismissals. Anais do XXIII Encontro da Sociedade Brasileira de Econometria.

Chang, C. \& Wang, Y. (1995). A framework for understanding differences in labor turnover and human capital investment. Journal of Economic Behaviour and organization, September.

Chang, C. \& Wang, Y. (1996). Human capital investment under asymmetric information: The Pigovian conjecture revisited. Journal of Labor Economics, 14(3):505-519.

Corseuil, C. H., Ribeiro, E. P., Santos, D., \& Servo, L. (2002). Job and worker flows in Brazil. In Menezes-Filho, N. A., editor, Labor Market Dynamics in Brazil. Inter-American Development Bank Research Network, 11th Round, FIPE-USP.

Doeringer, P. B. \& Piore, M. J. (1971). Internal labor markets and manpower analysis. D.C. Heath and Company and Heath Lexington books, Massachusetts.

Ehrenberg, R. \& Smith, R. (1994). Modern Labor Economics. Harper Collins. Fifth Edition.

Gonzaga, G. (1998). Rotatividade e qualidade do emprego no Brasil. Revista de Economia Politica.

Gonzaga, G. (2003). Labor turnover and labor legislation in Brasil. Economia, 4(1). Fall.

Greene, W. H. (1990). Econometrics Analysis. Macmillan Publishing Company, New York.

Gunderson, M. (1974). Retention of trainees: A study with dichotomous dependent variables. Journal of Econometrics, 2.

Hamermesh, D. S. \& Pfann, G. (1992). Turnover and the dynamics of labor demand. National Bureau of Economic Research, Working paper 4204, Cambridge, MA.

Heckman, J. (1978). Dummy endogenous variables in a simultaneous equation system. Econometrica, 46(6).

Katz, L. F. (1986). Efficiency wage theories: A partial evaluation. National Bureau of Economic Reserarch, Working paper 4034, Cambridge, MA. 
Lynch, L. M. (1992). Differential effects of post-school training on early career mobility. National Bureau of Economic Research, Working paper 4034, Cambridge, MA.

Menezes-Filho, N. \& Picchetti, P. (2000). Os determinantes da duração do desemprego em São Paulo. Pesquisa e Planejamento Econômico, 30(1).

Meng, C. \& Schmidt, P. (1985). On the cost of partial observability in the bivariate probit model. International Economic Review, 26(1):71-85.

Metcalf, D. (1987). Labour market flexibility and jobs: A survey of evidence from OECD countries with special reference to Europe. In Layard, R. \& Calmfors, L., editors, The Fight Against Unemployment: Macroeconomic Papers from the Center of European Studies, pages 51-76. MIT Press. First edition.

Milgron, P. \& Roberts, J. (1992). Economics, Organization and Management. Prentice-Hall International, Inc.

Mincer, J. (1978). Family migration decisions. Journal of Political Economy, 86(5):749-773.

Mincer, J. (1988). Job training, wage growth and labor turnover. National Bureau of Economic Research, Working paper 2690, Cambridge, MA, pp. 1-43.

Mincer, J. (1994). Human capital, a review. In Kerr, C. \& Staudohar, P. D., editors, Labor Economics and Industrial Relations: Markets and Institutions, pages 109-141. Wertheim publications in Industrial Relations.

Nickell, S. J. (1978). Fixed costs, employment and labour demand over the cycle. Economica, 45(11):329-345.

Nickell, S. J. (1986). Dynamic modles of labour demand. In Ashenfelter, O. \& Layard, R., editors, Handbook of Labor Economics, pages 473-522. NorthHolland, Amsterdam.

Nickell, S. J. (1995). Labour market dynamics in OECD countries. Discussion and working papers, Institute of Economics and Statistics, Oxford University, November 27 th.

Oi, W. (1962). Labor as a quasi-fixed factor. Journal of political economy, 4:538555 .

Orellano, V. I. F. (1997). Um estudo dos determinantes da rotatividade da mãode-obra na região metropolitana de São Paulo. Master's thesis, IPE-USP, São Paulo. 
Pfeffer, J. \& Cohen, Y. (1984). Determinants of internal labor markets in organizations. Administrative Science Quarterly, 29(4):550-572.

Poirier, D. J. (1980). Partial observability in bivariate probit models. Journal of Econometrics, 12:209-217.

Ribeiro, E. P. (2001). Rotatividade de trabalhadores e criação e destruição de postos de trabalho: Aspectos conceituais. IPEA, Texto para Discussão 820, Rio de Janeiro.

Rossi-Junior \& Ferreira (1999). Evolução da produtividade industrial brasileira e abertura comercial. Pesquisa e Planejamento Econômico, abril.

Rothenberg, T. J. (1971). Identification in parametric models. Econometrica, 39:577-591.

Williamson, O. E. (1985). The Economic Institutions of Capitalism: Firms, Markets, Relational Contracting. The Free Press, New York. 


\section{Appendix}

Table A.1 Bi-variate probit model supposing full observability

\begin{tabular}{|c|c|c|c|c|c|}
\hline Fire equation & Sector 1 & Sector 2 & Sector 3 & Sector 4 & Sector 5 \\
\hline gender (fem) & .0352307 & .0401462 & .0403471 & -.0366972 & .0875071 \\
\hline Head & -.0416411 & -.0539163 & .2454214 & .0498367 & .0461325 \\
\hline Age & .0107593 & .0167458 & .0042397 & .0233686 & .0152634 \\
\hline Educ & .0599793 & .0729176 & .0715087 & .0176912 & .0730478 \\
\hline Tenure & .0061098 & .0105283 & .0122813 & .0111461 & .0094979 \\
\hline Contr. & 1.53837 & 1.059465 & 1.187233 & .792224 & .6273701 \\
\hline Open_unemp & -.3795738 & -.2787416 & -.4990215 & -.4181323 & -.4728512 \\
\hline Dec88 & -.0284129 & .1878556 & -.0186184 & .0129865 & .2399117 \\
\hline dum90 & -.1253643 & -.1650849 & -.3383414 & -.120917 & -.2745807 \\
\hline dum91 & .2298491 & .0243607 & .0180771 & .3069819 & .1045842 \\
\hline dum92 & .4585622 & .2182067 & .4212012 & .7730122 & .445338 \\
\hline dum93 & .6720309 & .3404972 & .6278311 & .7087583 & .7051495 \\
\hline dum94 & .7174339 & .4191607 & .6057929 & .6748439 & .6320125 \\
\hline dum95 & .7130776 & .2988677 & .5864893 & .6026432 & .5277366 \\
\hline dum96 & 1.053424 & .4879037 & .7758525 & .8445145 & .8522529 \\
\hline dum97 & 1.107757 & .5406048 & .9270825 & 1.019143 & .969753 \\
\hline dum98 & 1.614832 & .8496801 & 1.477283 & 1.429535 & 1.485022 \\
\hline dum99 & 2.046425 & 1.242935 & 1.951079 & 2.003936 & 2.124014 \\
\hline Gdpvar & 1.53594 & 1.18846 & 1.74439 & -.1811668 & -.7484837 \\
\hline Constant & 2.309571 & 1.579248 & 3.381701 & 3.121573 & 3.387921 \\
\hline Quit equation & Sector 1 & Sector 2 & Sector 3 & Sector 4 & Sector 5 \\
\hline Gender (fem) & -.1262818 & -.1412477 & -.2341833 & -.1810372 & -.1426336 \\
\hline Head & .0827894 & .0916997 & .2192805 & .1686392 & .1080326 \\
\hline Age & .0141213 & .0230194 & .011679 & .0284766 & .0251968 \\
\hline Educ & .0464904 & .0540914 & .0061728 & .0109909 & .0718111 \\
\hline Tenure & .0059464 & .0105188 & .0122785 & .0117806 & .0126323 \\
\hline Contr. & 1.654448 & 1.365011 & 1.074783 & 1.335923 & 1.134731 \\
\hline Open_unemp & -.1250488 & -.1622876 & -.1606095 & -.2355593 & -.2591108 \\
\hline Dec88 & -.0798298 & .2460951 & .0094652 & -.0553352 & .1989715 \\
\hline dum90 & .1549682 & .0760854 & .0764645 & .0140695 & -.0506379 \\
\hline dum91 & .2842246 & .2654032 & .2424034 & .306023 & .2780664 \\
\hline dum92 & .5074998 & .3991418 & .4051679 & .6489914 & .4728483 \\
\hline dum93 & .5454405 & .4816489 & .7840067 & .6192042 & .6324841 \\
\hline dum94 & .5376673 & .443559 & .6312405 & .6031951 & .5673132 \\
\hline dum95 & .5440824 & .4931757 & .6168609 & .6315355 & .5191628 \\
\hline dum96 & .7672185 & .7362847 & .7409211 & .9255635 & .876128 \\
\hline dum97 & .7926086 & .8159995 & .9247378 & .8919255 & .9797305 \\
\hline dum98 & .9490591 & .9379974 & 1.128099 & 1.280053 & 1.275958 \\
\hline dum99 & 1.338152 & 1.196137 & 1.682875 & 1.748608 & 1.720312 \\
\hline Gdpvar & -.6809879 & -1.060919 & -.81414 & -.1183126 & -12.08746 \\
\hline Constant & .9860661 & 1.062759 & 1.692561 & 1.759791 & 1.707142 \\
\hline
\end{tabular}


Table A.2

Bi-Variate Probit Model Supposing Full Observability (Sector 1)

biprobit fire quit gender head age educ tenure contr. Open_unemp dec88
volatile dum90 dum91 dum92 dum93 dum94 dum95 dum96 dum97 dum98 dum99 gdpvar;

\begin{tabular}{|c|c|c|c|c|c|c|}
\hline \multicolumn{5}{|c|}{ Bivariate probit regression } & \multicolumn{2}{|c|}{$\begin{array}{l}\text { Number of obs }=73689 \\
\text { Wald chi2 }(40)=24632.22\end{array}$} \\
\hline & Coeff. & Std. Err & $z$ & $P>|z|$ & {$[95 \% \mathrm{Co}$} & Interval] \\
\hline $\begin{array}{l}\text { fire } \\
\text { gender }\end{array}$ & .0352307 & .0221263 & 1.59 & 0.111 & -.008136 & .0785975 \\
\hline head & -.0416411 & .0223384 & -1.86 & 0.062 & -.0854234 & .0021413 \\
\hline age & .0107593 & .0009543 & 11.28 & 0.000 & .0088889 & .0126296 \\
\hline educ & .0599793 & .0049264 & 12.18 & 0.000 & .0503237 & .069635 \\
\hline tenure & .0061098 & .0001966 & 31.08 & 0.000 & .0057245 & .0064951 \\
\hline contr. & 1.53837 & .0471837 & 32.60 & 0.000 & 1.445892 & 1.630849 \\
\hline Open_unemp & -.3795738 & .0162001 & -23.43 & 0.000 & -.4113254 & -.3478222 \\
\hline $\operatorname{dec} 88$ & $\begin{array}{l}-.0284129 \\
-.029\end{array}$ & .0474943 & $\begin{array}{l}-20.60 \\
-0.60\end{array}$ & 0.550 & $\begin{array}{l}-.4115204 \\
-.1215\end{array}$ & .0646743 \\
\hline volatile & -48.42554 & 7.737352 & -6.26 & 0.000 & -63.59047 & -33.26061 \\
\hline dum90 & -.1253643 & .0414077 & -3.03 & 0.002 & -.206522 & -.0442066 \\
\hline dum91 & .2298491 & .040431 & 5.68 & 0.000 & .1506058 & .3090924 \\
\hline dum92 & .4585622 & .0444684 & 10.31 & 0.000 & .3714057 & .5457187 \\
\hline dum 93 & .6720309 & .0513097 & 13.10 & 0.000 & .5714656 & .7725961 \\
\hline dum94 & .7174339 & .048891 & 14.67 & 0.000 & .6216094 & .8132585 \\
\hline dum95 & .7130776 & .0506424 & 14.08 & 0.000 & .6138204 & .8123348 \\
\hline dum96 & 1.053424 & .059353 & 17.75 & 0.000 & .9370939 & 1.169754 \\
\hline dum97 & 1.107757 & .0626942 & 17.67 & 0.000 & .9848788 & 1.230636 \\
\hline dum 98 & 1.614832 & .0789488 & 20.45 & 0.000 & 1.460095 & 1.769569 \\
\hline $\begin{array}{l}\text { dum99 } \\
\text { dums }\end{array}$ & $\begin{array}{l}1.0140325 \\
2.046425\end{array}$ & .0968333 & $\begin{array}{l}20.45 \\
21.13\end{array}$ & 0.000 & 1.856636 & 2.236215 \\
\hline gdpvar & 1.53594 & .2611899 & 5.88 & 0.000 & 1.024017 & 2.047862 \\
\hline -cons & 2.309571 & .1193567 & 19.35 & 0.000 & 2.075636 & 2.543506 \\
\hline quit & & & & & & \\
\hline gender & -.1262818 & .030917 & -4.08 & 0.000 & -.186878 & -.0656857 \\
\hline $\begin{array}{l}\text { head } \\
\text { hear }\end{array}$ & $\begin{array}{l}.0827894 \\
.0828\end{array}$ & .0357241 & $\begin{array}{l}-4.08 \\
2.32\end{array}$ & 0.020 & .0127716 & .1528073 \\
\hline age & .0141213 & .0014612 & 9.66 & 0.000 & .0112574 & .0169853 \\
\hline educ & .0464904 & .0077919 & 5.97 & 0.000 & .0312187 & .0617622 \\
\hline tenure & .0059464 & .0003355 & 17.72 & 0.000 & .0052888 & .0066041 \\
\hline contr. & 1.654448 & .0733372 & 22.56 & 0.000 & 1.51071 & 1.798186 \\
\hline Open_unemp & $\begin{array}{l}-.1250488 \\
-.1250\end{array}$ & .0232873 & -5.37 & 0.000 & -.1706911 & $\begin{array}{l}-.0794065 \\
-.0790\end{array}$ \\
\hline dec 88 - & $\begin{array}{l}-.1250480 \\
-.0798298\end{array}$ & .0762391 & $\begin{array}{l}-5.01 \\
-1.05\end{array}$ & 0.295 & $\begin{array}{l}-.1700911 \\
-.2292557\end{array}$ & .0695962 \\
\hline volatile & -4.479341 & 11.21781 & -0.40 & 0.690 & -26.46585 & 17.50717 \\
\hline dum 90 & .1549682 & .0617163 & 2.51 & 0.012 & .0340066 & .2759298 \\
\hline dum91 & .2842246 & .0554335 & 5.13 & 0.000 & .1755769 & .3928724 \\
\hline dum92 & .5074998 & .0670707 & 7.57 & 0.000 & .3760437 & .6389559 \\
\hline dum93 & .5454405 & .0769528 & 7.09 & 0.000 & .3946158 & .6962652 \\
\hline dum94 & .5376673 & .0697984 & 7.70 & 0.000 & .400865 & .6744697 \\
\hline dum95 & .5440824 & .0715266 & 7.61 & 0.000 & .4038928 & .684272 \\
\hline dum96 & $\begin{array}{l}.0440824 \\
.7672185\end{array}$ & .0848635 & $\begin{array}{l}.01 \\
9.04\end{array}$ & 0.000 & .6008892 & .9335478 \\
\hline dum97 & .7926086 & .0904059 & 8.77 & 0.000 & .6154162 & .9698009 \\
\hline dum98 & .9490591 & .109203 & 8.69 & 0.000 & .7350251 & 1.163093 \\
\hline $\begin{array}{l}\text { dum989 } \\
\text { dum99 }\end{array}$ & $\begin{array}{l}.9490591 \\
1.338152\end{array}$ & .1475531 & $\begin{array}{l}9.69 \\
9.07\end{array}$ & $\begin{array}{l}0.000 \\
0.000\end{array}$ & 1.048953 & $\begin{array}{l}1.103093 \\
1.62735\end{array}$ \\
\hline gdpvar & -.6809879 & .3658443 & -1.86 & 0.063 & -1.39803 & .0360537 \\
\hline _cons & .9860661 & .1731499 & $\begin{array}{l}-1.60 \\
5.69\end{array}$ & 0.000 & .6466985 & 1.325434 \\
\hline /athrho & -8.361176 & 36.96786 & -0.23 & 0.821 & -80.81684 & 64.09449 \\
\hline rho & -.9999999 & $8.08 \mathrm{e}-06$ & & & -1 & 1 \\
\hline
\end{tabular}


Table A.3 Bi-Variate Probit Model With Partial Observability (Sector 1)

biprobit fire quit gender head age educ tenure contr um92 dum93 dum94 dum95 dum96 dum97

\begin{tabular}{|c|c|c|c|c|c|c|}
\hline \multicolumn{5}{|c|}{$\begin{array}{l}\text { Partial observability bivariate probit } \\
\text { Loo likelihood }=-71716038\end{array}$} & \multicolumn{2}{|c|}{$\begin{array}{r}\text { Number of obs }=73689 \\
\text { Wald chi2 } 2(40)=8600.13 \\
\text { Prob }>\text { chi } 2=0.0000\end{array}$} \\
\hline & $\begin{array}{l}\text { Coeff. } \\
\end{array}$ & Std. Err. & $z$ & $P>|z|$ & & Interval] \\
\hline \multicolumn{7}{|c|}{ 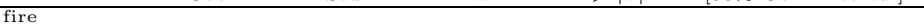 } \\
\hline gender & .0434045 & .0680368 & 0.64 & 0.524 & -.0899452 & .1767542 \\
\hline head & -.0226512 & .661455 & -0.34 & 0.732 & -.152294 & .1069916 \\
\hline age & .0141564 & .0028035 & 5.05 & 0.000 & .0086616 & .0196511 \\
\hline educ & .0650094 & .0144643 & 4.49 & 0.000 & .0366599 & .093359 \\
\hline tenure & .0037876 & .0004985 & 7.60 & 0.000 & .0028106 & .0047646 \\
\hline contr. & -1.952644 & .1732449 & -11.27 & 0.000 & -2.292198 & -1.613091 \\
\hline open_unemp & -18.67143 & .6056775 & -30.83 & 0.000 & -19.85853 & -17.48432 \\
\hline $\operatorname{dec} 88$ & 3.437922 & .1752672 & 19.62 & 0.000 & 3.094404 & 3.781439 \\
\hline volatile & 1094.07 & 59.62661 & 18.35 & 0.000 & 977.2037 & 1210.936 \\
\hline dum90 & -7.227683 & .3246612 & -22.26 & 0.000 & -7.864008 & -6.591359 \\
\hline dum91 & 13.10596 & .5159498 & 25.40 & 0.000 & 12.09471 & 14.1172 \\
\hline dum92 & 33.99629 & 1.129509 & 30.10 & 0.000 & 31.78249 & 36.21009 \\
\hline dum93 & 39.88956 & 1.288753 & 30.95 & 0.000 & 37.36366 & 42.41547 \\
\hline dum94 & 29.70863 & .9526881 & 31.18 & 0.000 & 27.84139 & 31.57586 \\
\hline dum95 & 29.23824 & .9442003 & 30.97 & 0.000 & 27.38764 & 31.08884 \\
\hline dum96 & 47.4491 & 1.539097 & 30.83 & 0.000 & 44.43252 & 50.46567 \\
\hline dum 97 & 51.84625 & 1.689745 & 30.68 & 0.000 & 48.53441 & 55.15809 \\
\hline dum98 & 77.49315 & 2.493947 & 31.07 & 0.000 & 72.60511 & 82.3812 \\
\hline dum99 & 87.67844 & 7.395298 & 11.86 & 0.000 & 73.18392 & 102.173 \\
\hline gdpvar & 60.64638 & 2.170279 & 27.94 & 0.000 & 56.39271 & 64.90005 \\
\hline -cons & 130.8711 & 4.226415 & 30.97 & 0.000 & 122.5874 & 139.1547 \\
\hline \multicolumn{7}{|l|}{ quit } \\
\hline gender & -.0589781 & .0335601 & -1.76 & 0.079 & -.1247547 & .0067986 \\
\hline head & -.0118676 & .0341065 & -0.35 & 0.728 & -.078715 & .0549799 \\
\hline age & .0147756 & .0014292 & 10.34 & 0.000 & .0119744 & .0175768 \\
\hline educ & .0770168 & .0074883 & 10.28 & 0.000 & .06234 & .0916935 \\
\hline tenure & .0066853 & .0003018 & 22.15 & 0.000 & .0060937 & .0072769 \\
\hline contr. & 2.407705 & .0699283 & 34.43 & 0.000 & 2.270648 & 2.544761 \\
\hline Open_unemp & 2.318052 & .0489386 & 47.37 & 0.000 & 2.222134 & 2.413969 \\
\hline $\operatorname{dec} 88$ & -.7434192 & .0711131 & -10.45 & 0.000 & $\begin{array}{r}-.8827984 \\
\end{array}$ & -.60404 \\
\hline volatile & -44.99974 & 13.39934 & -3.36 & 0.001 & -71.26196 & -18.73753 \\
\hline dum90 & .835179 & .0550535 & 15.17 & 0.000 & .727276 & .9430819 \\
\hline dum91 & -1.493514 & .0746935 & -20.00 & 0.000 & -1.63991 & -1.347117 \\
\hline dum92 & -3.036671 & .0827375 & -36.70 & 0.000 & -3.198834 & -2.874509 \\
\hline dum93 & -4.681018 & .1125512 & -41.59 & 0.000 & -4.901614 & -4.460422 \\
\hline dum94 & -4.011902 & .1050102 & -38.20 & 0.000 & -4.217718 & -3.806086 \\
\hline dum95 & -3.806077 & .1211192 & -31.42 & 0.000 & -4.043466 & -3.568688 \\
\hline dum96 & -5.38341 & .136132 & -39.55 & 0.000 & -5.650224 & -5.116596 \\
\hline dum 97 & -6.355623 & .1672998 & -37.99 & 0.000 & -6.683525 & -6.027722 \\
\hline dums & -8.53799 & .1943355 & -43. & 0.0 & -8.918882 & -8.157101 \\
\hline dum99 & -10.75788 & .263807 & -40.78 & 0.000 & -11.27493 & -10.24083 \\
\hline gdpvar & -6.23445 & .8066165 & -7.73 & 0.000 & -7.81539 & -4.653511 \\
\hline -cons & -16.28598 & .3417294 & -47.66 & 0.000 & -16.95575 & -15.6162 \\
\hline athrho & -611.4712 & 229.9769 & -2.66 & 0.008 & -1062.218 & -160.7248 \\
\hline rho & -1 & 0 & & & -1 & -1 \\
\hline
\end{tabular}


Table A.4

Bi-Variate Probit Model Supposing Full Observability (Sector 2)

biprobit fire quit gender head age educ tenure contr.open_unemp dec 88
volatile dum90 dum91 dum92 dum93 dum94 dum95 dum96 dum97 dum98 dum99 gdpvar;

\begin{tabular}{|c|c|c|c|c|c|c|}
\hline \multicolumn{5}{|c|}{ Bivariate probit regression } & \multicolumn{2}{|c|}{$\begin{array}{l}\text { Number of obs }=60168 \\
\text { Wald chi2 }(40)=13994.86\end{array}$} \\
\hline & Coeff. & Std. Err. & $z$ & $P>|z|$ & \multicolumn{2}{|c|}{$[95 \%$ Conf.Interval $]$} \\
\hline \multicolumn{7}{|l|}{ fire } \\
\hline gender & .0401462 & .0192322 & 2.09 & 0.037 & .0024518 & .0778407 \\
\hline head & -.0539163 & .0227201 & -2.37 & 0.018 & -.0984469 & -.0093856 \\
\hline age & .0167458 & .0008826 & 18.97 & 0.000 & .015016 & .0184756 \\
\hline educ & .0729176 & .0054371 & 13.41 & 0.000 & .062261 & .0835742 \\
\hline tenure & .0105283 & .0002469 & 42.64 & 0.000 & .0100444 & .0110122 \\
\hline contr. & 1.059465 & .0535641 & 19.78 & 0.000 & .9544808 & 1.164448 \\
\hline open_unemp & -.2787416 & .0161327 & -17.28 & 0.000 & -.3103612 & -.247122 \\
\hline $\operatorname{dec} 88$ & .1878556 & .0552903 & 3.40 & 0.001 & .0794886 & .2962227 \\
\hline volatile & -19.36072 & 8.217648 & -2.36 & 0.018 & -35.46701 & -3.254425 \\
\hline dum90 & -.1650849 & .0433405 & -3.81 & 0.000 & -.2500307 & -.0801391 \\
\hline dum91 & .0243607 & .0428847 & 0.57 & 0.570 & -.0596918 & .1084132 \\
\hline dum92 & .2182067 & .0452283 & 4.82 & 0.000 & .129561 & .3068525 \\
\hline dum93 & .3404972 & .0503596 & 6.76 & 0.000 & .2417942 & .4392002 \\
\hline dum94 & .4191607 & .0490013 & 8.55 & 0.000 & .32312 & .5152015 \\
\hline dum95 & .2988677 & .0523236 & 5.71 & 0.000 & .1963154 & .40142 \\
\hline dum96 & .4879037 & .0595781 & 8.19 & 0.000 & .3711329 & .6046746 \\
\hline dum97 & .5406048 & .0631275 & 8.56 & 0.000 & .4168772 & .6643323 \\
\hline dum98 & .8496801 & .0811941 & 10.46 & 0.000 & .6905426 & 1.008818 \\
\hline dum99 & 1.242935 & .1001669 & 12.41 & 0.000 & 1.046612 & 1.439259 \\
\hline gdpvar & 1.18846 & .2582803 & 4.60 & 0.000 & .6822402 & 1.69468 \\
\hline -cons & 1.579248 & .1181864 & 13.36 & 0.000 & 1.347607 & 1.81089 \\
\hline \multicolumn{7}{|l|}{ quit } \\
\hline gender & -.1412477 & .0255861 & -5.52 & 0.000 & -.1913956 & -.0910998 \\
\hline head & .0916997 & .0336365 & 2.73 & 0.006 & .0257734 & .1576259 \\
\hline age & .0230194 & .0012602 & 18.27 & 0.000 & .0205494 & .0254894 \\
\hline educ & .0540914 & .0076933 & 7.03 & 0.000 & .0390128 & .06917 \\
\hline tenure & .0105188 & .0003655 & 28.78 & 0.000 & .0098024 & .0112352 \\
\hline contr. & 1.365011 & .0778007 & 17.54 & 0.000 & 1.212525 & 1.517498 \\
\hline open_unemp & -.1622876 & .0226577 & -7.16 & 0.000 & -.2066958 & -.1178794 \\
\hline dec 88 & .2460951 & .0851272 & 2.89 & 0.004 & .0792489 & .4129413 \\
\hline volatile & $\begin{array}{l}.2400901 \\
-7.9166\end{array}$ & $\begin{array}{l}.0831289 \\
11.34889\end{array}$ & $\begin{array}{l}.09 \\
-0.70\end{array}$ & 0.485 & $\begin{array}{r}.0792489 \\
-30.16002\end{array}$ & 14.32682 \\
\hline dum90 & .0760854 & .0565214 & 1.35 & 0.178 & -.0346946 & .1868654 \\
\hline dum91 & .2654032 & .0568103 & 4.67 & 0.000 & .154057 & .3767494 \\
\hline dum92 & .3991418 & .0607697 & 6.57 & 0.000 & .2800354 & .5182483 \\
\hline dum93 & .4816489 & .0687445 & 7.01 & 0.000 & .3469122 & .6163856 \\
\hline dum94 & .443559 & .0643255 & 6.90 & 0.000 & .3174832 & .5696347 \\
\hline dum 95 & .4931757 & .0696218 & 7.08 & 0.000 & .3567194 & .6296319 \\
\hline dum96 & .7362847 & .0821551 & 8.96 & 0.000 & .5752637 & .8973057 \\
\hline dum 97 & .8159995 & .0866853 & 9.41 & 0.000 & .6460994 & .9858995 \\
\hline dum98 & .9379974 & .1104916 & 8.49 & 0.000 & .7214378 & 1.154557 \\
\hline $\begin{array}{l}\text { dum99 } \\
\text { dum }\end{array}$ & 1.196137 & .1387465 & $\begin{array}{l}8.62 \\
8.62\end{array}$ & 0.000 & .9241991 & 1.468075 \\
\hline gdpvar & -1.060919 & .3064968 & -3.46 & 0.001 & -1.661641 & -.4601961 \\
\hline -cons & 1.062759 & .1662903 & 6.39 & 0.000 & .7368355 & 1.388682 \\
\hline /athrho & -8.022917 & 39.80941 & -0.20 & 0.840 & -86.04793 & 70.00209 \\
\hline rho & -.9999998 & .0000171 & & & -1 & 1 \\
\hline & & & & & & \\
\hline
\end{tabular}


Table A.5 Bi-Variate Probit Model With Partial Observability (Sector 2)

biprobit fire quit gender head age educ tenure contr. Open_unemp dec 88
volatile dum90 dum91 dum92 dum93 dum94 dum95 dum96 dum97 dum98 dum99 gdpvar, partial difficult from (coefss);

\begin{tabular}{|c|c|c|c|c|c|c|}
\hline \multicolumn{5}{|c|}{$\begin{array}{l}\text { Partial observability bivariate probit } \\
\text { Log likelihood }=-7493.7865\end{array}$} & \multicolumn{2}{|c|}{$\begin{array}{r}\text { Number of obs }=60168 \\
\text { Wald chi } 2(40)=8311.13 \\
\text { Prob }>\text { chi } 2=0.0000\end{array}$} \\
\hline & Coeff. & Std. Err. & $z$ & $P>|z|$ & & \\
\hline \multicolumn{7}{|c|}{ 年 } \\
\hline gender & .0575158 & .0455467 & 1.26 & 0.207 & -.031754 & .1467857 \\
\hline head & -.0281923 & .0507607 & -0.56 & 0.579 & -.1276815 & .0712969 \\
\hline age & .0228815 & .0020966 & 10.91 & 0.000 & .0187723 & .0269907 \\
\hline educ & .0720952 & .0124505 & 5.79 & 0.000 & .0476927 & .0964977 \\
\hline tenure & .0099313 & .0005228 & 19.00 & 0.000 & .0089065 & .010956 \\
\hline contr. & -1.056315 & .1248434 & -8.46 & 0.000 & -1.301003 & -.8116263 \\
\hline open_unemp & -13.54039 & .3505575 & -38.63 & 0.000 & -14.22747 & -12.85331 \\
\hline $\operatorname{dec} 88$ & 2.587495 & .1340384 & 19.30 & 0.000 & 2.324785 & 2.850206 \\
\hline volatile & 963.3092 & 39.74892 & 24.23 & 0.000 & 885.4028 & 1041.216 \\
\hline dum90 & -6.062392 & .2174625 & -27.88 & 0.000 & -6.48861 & -5.636173 \\
\hline dum91 & 9.06146 & .2454291 & 36.92 & 0.000 & 8.580428 & 9.542493 \\
\hline dum92 & 24.59557 & .6530141 & 37.66 & 0.000 & 23.31569 & 25.87546 \\
\hline dum93 & 29.27076 & .754085 & 38.82 & 0.000 & 27.79278 & 30.74874 \\
\hline dum 94 & 21.33123 & .5568245 & 38.31 & 0.000 & 20.23988 & 22.42259 \\
\hline dum 95 & 20.7273 & .5573783 & 37.19 & 0.000 & 19.63486 & 21.81974 \\
\hline dum96 96 & 33.33077 & .8700109 & 38.31 & 0.000 & 31.62558 & 35.03596 \\
\hline dum 97 & 36.41492 & .9454118 & 38.52 & 0.000 & 34.56194 & 38.26789 \\
\hline dum 98 & 55.55901 & 1.444473 & 38.46 & 0.000 & 52.72789 & 58.39012 \\
\hline dum99 & 61.46879 & 1.83826 & 33.44 & 0.000 & 57.86586 & 65.07171 \\
\hline gdpvar & 48.76103 & 1.716527 & 28.41 & 0.000 & 45.3967 & 52.12536 \\
\hline$-\operatorname{cons}$ & 93.81797 & 2.432751 & 38.56 & 0.000 & 89.04987 & 98.58607 \\
\hline \multicolumn{7}{|l|}{ quit } \\
\hline gender & -.0284509 & .0295457 & -0.96 & 0.336 & -.0863595 & .0294576 \\
\hline head & -.0446279 & .0347296 & -1.29 & 0.199 & -.1126966 & .0234408 \\
\hline age & .0248164 & .0013635 & 18.20 & 0.000 & .0221439 & .0274889 \\
\hline educ & .0933057 & .0083251 & 11.21 & 0.000 & .0769888 & .1096227 \\
\hline tenure & .0117382 & .0003794 & 30.94 & 0.000 & .0109946 & .0124818 \\
\hline contr. & 1.872766 & .0792791 & 23.62 & 0.000 & 1.717382 & 2.028151 \\
\hline Open_unemp & 2.572859 & .0472612 & 54.44 & 0.000 & 2.480228 & 2.665489 \\
\hline $\operatorname{dec} 88$ & -.4038448 & .0830331 & -4.86 & 0.000 & -.5665868 & -.2411029 \\
\hline volatile & 1.408893 & 11.84604 & 0.12 & 0.905 & -21.80893 & 24.62671 \\
\hline dum90 & .600227 & .0556242 & 10.79 & 0.000 & .4912055 & .7092485 \\
\hline dum91 & -2.241585 & .0726863 & -30.84 & 0.000 & $\begin{array}{r}-2.384048 \\
\end{array}$ & -2.099123 \\
\hline dum92 & -3.641634 & .0848614 & -42.91 & 0.000 & -3.80796 & -3.475309 \\
\hline dum93 & -5.513964 & .1120687 & -49.20 & 0.000 & -5.733614 & -5.294313 \\
\hline dum 94 & -4.851542 & .1052571 & -46.09 & 0.000 & -5.057842 & -4.645242 \\
\hline dum95 & -4.780431 & .1219595 & -39.20 & 0.000 & -5.019467 & -4.541394 \\
\hline dum 96 & -6.463096 & .133124 & -48.55 & 0.000 & -6.724014 & -6.202178 \\
\hline dum 97 & -7.215278 & .1630737 & -44.25 & 0.000 & -7.534897 & -6.89566 \\
\hline dum98 & -10.07081 & .1924303 & -52.33 & 0.000 & -10.44797 & -9.693654 \\
\hline dum 99 & -12.69578 & .2548655 & -49.81 & 0.000 & -13.19531 & -12.19625 \\
\hline gdpvar & -18.37236 & .5576397 & -32.95 & 0.000 & -19.46531 & -17.27941 \\
\hline -cons & -18.08385 & .3295252 & -54.88 & 0.000 & -18.72971 & $\begin{array}{r}-17.43799 \\
\end{array}$ \\
\hline athrho & 1094.819 & 51.56425 & 21.23 & 0.000 & 993.7551 & 1195.883 \\
\hline rho & & & & & -1 & 1 \\
\hline
\end{tabular}


Table A.6 Bi-Variate Probit Model Supposing Full Observability (Sector 3)

biprobit fire quit gender head age educ tenure contr. Open_unemp dec 88 dum 90 dum91 dum92 dum93 dum94 dum95 dum96 dum97 dum98 dum99 gdpvar,

\begin{tabular}{|c|c|c|c|c|c|c|}
\hline \multicolumn{5}{|c|}{ Bivariate probit regression } & \multicolumn{2}{|c|}{$\begin{array}{l}\text { Number of obs }=23261 \\
\text { Wald chi2 }(38)=7811.37\end{array}$} \\
\hline & Coeff. & Std. Err. & $z$ & $P>|z|$ & {$[95 \% \mathrm{Co}$} & Interval] \\
\hline \multicolumn{7}{|l|}{ fire } \\
\hline gender & .0403471 & .0682966 & 0.59 & 0.555 & -.0935117 & .1742059 \\
\hline head & .2454214 & .0294409 & 8.34 & 0.000 & .1877182 & .3031246 \\
\hline age & .0042397 & .0010711 & 3.96 & 0.000 & .0021404 & .0063391 \\
\hline educ & .0715087 & .0087335 & 8.19 & 0.000 & .0543913 & .088626 \\
\hline tenure & .0122813 & .0002927 & 41.95 & 0.000 & .0117076 & .0128551 \\
\hline contr. & 1.187233 & .148248 & 8.01 & 0.000 & .8966718 & 1.477793 \\
\hline open_unemp & -.4990215 & .0218302 & -22.86 & 0.000 & -.541808 & -.4562351 \\
\hline $\operatorname{dec} 88$ & -.0186184 & .1515075 & -0.12 & 0.902 & -.3155676 & .2783308 \\
\hline dum90 & -.3383414 & .0583185 & -5.80 & 0.000 & -.4526436 & -.2240391 \\
\hline dum91 & .0180771 & .0578137 & 0.31 & 0.755 & -.0952357 & .1313898 \\
\hline dum92 & .4212012 & .0693613 & 6.07 & 0.000 & .2852556 & .5571468 \\
\hline dum 93 & .6278311 & .0711694 & 8.82 & 0.000 & .4883417 & .7673205 \\
\hline dum 94 & .6057929 & .0709795 & 8.53 & 0.000 & .4666756 & .7449102 \\
\hline dum95 & .5864893 & .072667 & 8.07 & 0.000 & .4440645 & .728914 \\
\hline dum96 & .7758525 & .0810538 & 9.57 & 0.000 & .61699 & .934715 \\
\hline $\begin{array}{l}\text { dum } 97 \\
\text { dut }\end{array}$ & .9270825 & .0871818 & 10.63 & 0.000 & .7562094 & 1.097956 \\
\hline dum 98 & 1.477283 & .1101554 & 13.41 & 0.000 & 1.261382 & 1.693183 \\
\hline dum99 & 1.951079 & .125526 & 15.54 & 0.000 & 1.705053 & 2.197106 \\
\hline gdpvar & 1.74439 & .3695408 & 4.72 & 0.000 & 1.020104 & 2.468677 \\
\hline -cons & 3.381701 & .1745772 & 19.37 & 0.000 & 3.039536 & 3.723866 \\
\hline \multicolumn{7}{|l|}{ quit } \\
\hline gender & -.2341833 & .0926321 & -2.53 & 0.011 & -.4157389 & -.0526278 \\
\hline head & .2192805 & .048377 & 4.53 & 0.000 & .1244633 & .3140976 \\
\hline age & .011679 & .0019204 & 6.08 & 0.000 & .007915 & .015443 \\
\hline educ & .0061728 & .0139441 & 0.44 & 0.658 & -.0211571 & .0335028 \\
\hline tenure & .0122785 & .0005768 & 21.29 & 0.000 & .011148 & .013409 \\
\hline contr. & 1.074783 & .1717058 & 6.26 & 0.000 & .7382455 & 1.41132 \\
\hline open_unemp & $\begin{array}{l}-.1606095 \\
-.16\end{array}$ & .033476 & -4.80 & 0.000 & -.2262212 & $\begin{array}{l}-.0949977 \\
\end{array}$ \\
\hline $\operatorname{dec} 88$ & .0094652 & .1822506 & 0.05 & 0.959 & -.3477393 & .3666698 \\
\hline dum 90 & .0764645 & .0721904 & 1.06 & 0.290 & -.0650261 & .2179551 \\
\hline dum91 & .2424034 & .0781621 & 3.10 & 0.002 & .0892085 & .3955982 \\
\hline dum 92 & .4051679 & .099802 & 4.06 & 0.000 & .2095595 & .6007763 \\
\hline dum93 & .7840067 & .1106168 & 7.09 & 0.000 & .5672017 & 1.000812 \\
\hline dum 94 & .6312405 & .1055317 & 5.98 & 0.000 & .4244021 & .8380789 \\
\hline dum 95 & .6168609 & .1090945 & 5.65 & 0.000 & .4030396 & .8306822 \\
\hline dum96 & .7409211 & .1225933 & 6.04 & 0.000 & .5006426 & .9811996 \\
\hline dum 97 & .9247378 & .1336596 & 6.92 & 0.000 & .6627699 & 1.186706 \\
\hline dum98 & 1.128099 & .1697227 & 6.65 & 0.000 & .7954484 & 1.460749 \\
\hline dum 99 & 1.682875 & .208148 & 8.08 & 0.000 & 1.274912 & 2.090837 \\
\hline gdpvar & -.81414 & .572918 & -1.42 & 0.155 & -1.937039 & .3087587 \\
\hline -cons & 1.692561 & .2739312 & 6.18 & 0.000 & 1.155665 & 2.229456 \\
\hline Fathrho & -8.378458 & 67.12656 & -0.12 & 0.901 & -139.9441 & 123.1872 \\
\hline rho & -.9999999 & .0000142 & & & -1 & 1 \\
\hline
\end{tabular}


Table A.7 Bi-Variate Probit With Partial Observability (Sector 3)

biprobit fire quit gender head age educ tenure contr. Open_unemp dec 88 dum 90

dum91 dum92 dum93 dum94 dum95 dum96 dum97 dum98 dum99 gdpvar, partial difficult from (coefss):

\begin{tabular}{|c|c|c|c|c|c|c|}
\hline \multicolumn{5}{|c|}{ Partial observability bivariate probit } & \multicolumn{2}{|c|}{$\begin{array}{l}\text { Number of obs }=23261 \\
\text { Wald chi } 2(38)=1485.86 \\
\text { Prob }>\text { chi } 2=0.0000\end{array}$} \\
\hline & Coeff. & Std. Err. & $z$ & $P>|z|$ & {$[95 \% \mathrm{C}$} & f.Interval] \\
\hline fire & & & & & & \\
\hline gender & -.1415639 & .0729773 & -1.94 & 0.052 & -.2845967 & .001469 \\
\hline head & .2051396 & .0354109 & 5.79 & 0.000 & .1357356 & .2745437 \\
\hline age & .0058387 & .0012661 & 4.61 & 0.000 & .0033573 & .0083202 \\
\hline educ & .0262907 & .0095916 & 2.74 & 0.006 & .0074915 & .04509 \\
\hline tenure & .0030916 & .0002811 & 11.00 & 0.000 & .0025407 & .0036425 \\
\hline contr. & .93876 & .1609903 & 5.83 & 0.000 & .6232248 & 1.254295 \\
\hline open_unemp & -.6508156 & .0295595 & -22.02 & 0.000 & -.7087511 & -.5928801 \\
\hline $\operatorname{dec} 88$ & -.0719113 & .1642719 & -0.44 & 0.662 & $\begin{array}{l}. \\
-.3938784\end{array}$ & .2500557 \\
\hline dum90 & -.3564335 & .0672756 & -5.30 & 0.000 & -.4882913 & -.2245757 \\
\hline dum91 & .2247531 & .0667296 & 3.37 & 0.001 & .0939656 & .3555407 \\
\hline dum92 & .7673557 & .0824682 & 9.30 & 0.000 & .6057211 & .9289904 \\
\hline dum93 & 1.16277 & .0901983 & 12.89 & 0.000 & .9859847 & 1.339556 \\
\hline dum94 & 1.036434 & .0866256 & 11.96 & 0.000 & .8666505 & 1.206217 \\
\hline dum95 & 1.029665 & .0877707 & 11.73 & 0.000 & .8576378 & 1.201692 \\
\hline dum96 & 1.331943 & .1018538 & 13.08 & 0.000 & 1.132314 & 1.531573 \\
\hline dum97 & 1.635187 & .11114 & 14.71 & 0.000 & 1.417357 & 1.853017 \\
\hline dum98 & 2.324668 & .1431772 & 16.24 & 0.000 & 2.044046 & 2.60529 \\
\hline dum99 & 3.000136 & .1645285 & 18.23 & 0.000 & 2.677666 & 3.322606 \\
\hline gdpvar & 2.254007 & .4575949 & 4.93 & 0.000 & 1.357138 & 3.150877 \\
\hline -cons & 5.436422 & .2254568 & 24.11 & 0.000 & 4.994535 & 5.87831 \\
\hline quit & & & & & & \\
\hline gender & -.1913158 & .3199146 & -0.60 & 0.550 & -.818337 & .4357053 \\
\hline head & .3124811 & .1487498 & 2.10 & 0.036 & .0209367 & .6040254 \\
\hline age & .0022508 & .0054971 & 0.41 & 0.682 & -.0085232 & .0130249 \\
\hline educ & .0478361 & .0523914 & 0.91 & 0.361 & -.0548492 & .1505214 \\
\hline tenure & 1.618773 & .1354364 & 11.95 & 0.000 & 1.353322 & 1.884223 \\
\hline contr. & 2.482514 & 4.914493 & 0.51 & 0.613 & -7.149715 & 12.11474 \\
\hline open_unemp & 1.642181 & .2156687 & 7.61 & 0.000 & 1.219478 & 2.064884 \\
\hline $\operatorname{dec} 88$ & -1.791896 & 4.916239 & -0.36 & 0.715 & -11.42755 & 7.843755 \\
\hline dum90 & .1758988 & .3160055 & 0.56 & 0.578 & -.4434606 & .7952583 \\
\hline dum91 & -1.949461 & .3676386 & -5.30 & 0.000 & -2.670019 & -1.228902 \\
\hline dum92 & -2.498116 & .4531653 & -5.51 & 0.000 & -3.386303 & -1.609928 \\
\hline dum93 & -4.096513 & .5731863 & -7.15 & 0.000 & -5.219937 & -2.973088 \\
\hline dum94 & -3.445245 & .5826805 & -5.91 & 0.000 & -4.587278 & -2.303212 \\
\hline dum95 & -3.812908 & .5911462 & -6.45 & 0.000 & -4.971533 & -2.654283 \\
\hline dum96 & -4.634096 & .6571422 & -7.05 & 0.000 & -5.922071 & -3.346121 \\
\hline dum97 & -5.65397 & .7703934 & -7.34 & 0.000 & -7.163913 & -4.144027 \\
\hline dum98 & -6.655647 & .9239364 & -7.20 & 0.000 & -8.466529 & -4.844765 \\
\hline dum99 & -8.928589 & 1.198129 & -7.45 & 0.000 & -11.27688 & -6.580299 \\
\hline gdpvar & -4.479619 & 2.094276 & -2.14 & 0.032 & -8.584325 & -.3749126 \\
\hline$-\operatorname{cons}$ & -29.23619 & 2.877918 & -10.16 & 0.000 & -34.8768 & -23.59557 \\
\hline athrho & 617.6828 & 81.31443 & 7.60 & 0.000 & 458.3094 & 777.0561 \\
\hline rho & 1 & 0 & & & 1 & 1 \\
\hline
\end{tabular}


Table A.8

Bi-Variate Probit Model Supposing Observability (Sector 4)

biprobit fire quit gender head age educ tenure contr. open_unemp dec 88 dum 90

dum91 dum92 dum93 dum94 dum95 dum96 dum97 dum98 dum99 gdpvar,

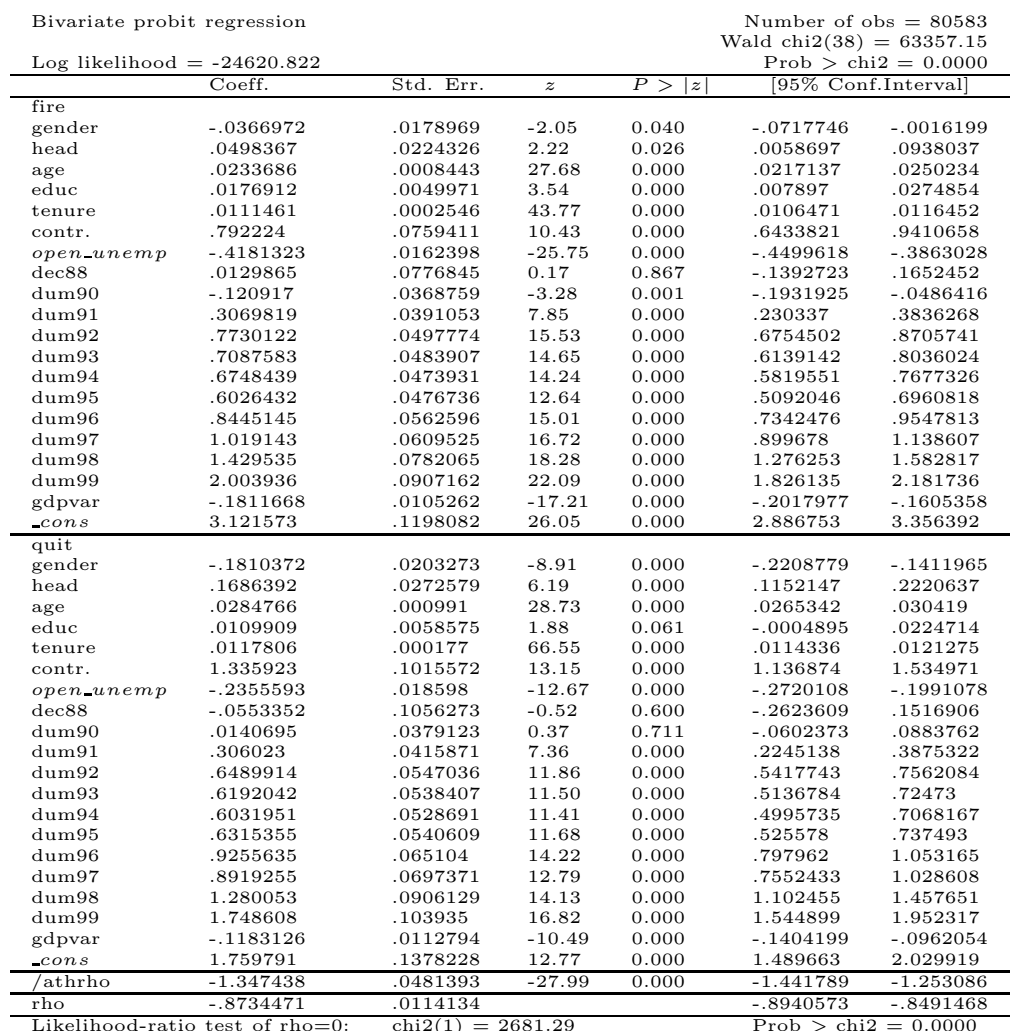


Table A.9 Bi-Variate Probit Model With Partial Observability (Sector 4)

biprobit fire quit gender head age educ tenure contr. open_unemp dec 88 dum 90 dum91 dum92 dum93 dum94 dum95 dum96 dum97 dum98 dum99 gdpvar, partial difficult from (coefss);

\begin{tabular}{|c|c|c|c|c|c|c|}
\hline \multicolumn{5}{|c|}{ Partial observability bivariate probit } & \multicolumn{2}{|c|}{$\begin{array}{r}\text { Number of obs }=80583 \\
\text { Wald chi2 } 2(38)=4236.43 \\
\text { Prob }>\text { chi2 }=0.0000\end{array}$} \\
\hline & Coeff. & Std. Err. & $z$ & $P>|z|$ & {$[95 \% \mathrm{C}$} & f.Interval] \\
\hline \multicolumn{7}{|l|}{ fire } \\
\hline $\begin{array}{l}\text { gender } \\
\text { head }\end{array}$ & $\begin{array}{l}-.0506884 \\
.0826166\end{array}$ & $\begin{array}{l}.0198398 \\
.0235618\end{array}$ & $\begin{array}{l}-2.55 \\
3.51\end{array}$ & $\begin{array}{l}0.011 \\
0.000\end{array}$ & $\begin{array}{c}-.0895737 \\
.0364362\end{array}$ & $\begin{array}{r}-.011803 \\
.1287969\end{array}$ \\
\hline $\begin{array}{l}\text { head } \\
\text { age }\end{array}$ & .024396 & .0008923 & 27.34 & 0.000 & .022647 & .0261449 \\
\hline educ & .0120759 & .0051745 & 2.33 & 0.020 & .0019341 & .0222178 \\
\hline tenure & .0029784 & .0001951 & 15.27 & 0.000 & .0025961 & .0033607 \\
\hline contr. & .8231948 & .0823345 & 10.00 & 0.000 & .6618222 & .9845675 \\
\hline open_unemp & -.7083143 & .020077 & -35.28 & 0.000 & -.7476645 & -.668964 \\
\hline $\operatorname{dec} 88$ & -.1011021 & .0838245 & -1.21 & 0.228 & $\begin{array}{l}-.2653952 \\
-\end{array}$ & .063191 \\
\hline dum90 & -.1936204 & .0387995 & -4.99 & 0.000 & -.269666 & -.1175748 \\
\hline dum91 & .5361646 & .0412777 & 12.99 & 0.000 & .4552619 & .6170674 \\
\hline dum92 & 1.382422 & .0576032 & 24.00 & 0.000 & 1.269522 & 1.495322 \\
\hline dum93 & 1.391753 & .0556437 & 25.01 & 0.000 & 1.282693 & 1.500812 \\
\hline dum94 & 1.310186 & .0537281 & 24.39 & 0.000 & 1.204881 & 1.415491 \\
\hline dum95 & 1.278208 & .0543535 & 23.52 & 0.000 & 1.171678 & 1.384739 \\
\hline dum96 & 1.75107 & .0659743 & 26.54 & 0.000 & 1.621763 & 1.880378 \\
\hline dum97 & 2.022718 & .0717595 & 28.19 & 0.000 & 1.882071 & 2.163364 \\
\hline dum98 & 2.776627 & .0944048 & 29.41 & 0.000 & 2.591597 & 2.961657 \\
\hline dum99 & 3.707618 & .1105368 & 33.54 & 0.000 & 3.49097 & 3.924266 \\
\hline gdpvar & -.2985771 & .0163462 & -18.27 & 0.000 & -.3306151 & -.266539 \\
\hline cons & 5.43897 & .1457515 & 37.32 & 0.000 & 5.153303 & 5.724638 \\
\hline \multicolumn{7}{|l|}{ quit } \\
\hline gender & .045188 & .1154914 & 0.39 & 0.696 & -.1811709 & .271547 \\
\hline head & .0483844 & .1319565 & 0.37 & 0.714 & -.2102456 & .3070145 \\
\hline age & .0249699 & .0048514 & 5.15 & 0.000 & .0154613 & .0344784 \\
\hline educ & .0256673 & .0361253 & 0.71 & 0.477 & -.045137 & .0964715 \\
\hline tenure & 4.839468 & .365562 & 13.24 & 0.000 & 4.122979 & 5.555956 \\
\hline contr. & 4.103745 & 134.2984 & 0.03 & 0.976 & -259.1163 & 267.3238 \\
\hline open_unemp & 5.015045 & .4608656 & 10.88 & 0.000 & 4.111765 & 5.918325 \\
\hline $\operatorname{dec} 88$ & -3.49988 & 134.2985 & -0.03 & 0.979 & -266.72 & 259.7203 \\
\hline dum90 & 2.350505 & .5092575 & 4.62 & 0.000 & 1.352378 & 3.348631 \\
\hline dum91 & -4.094479 & .5083757 & -8.05 & 0.000 & -5.090877 & -3.098081 \\
\hline dum92 & -6.55371 & .8005341 & -8.19 & 0.000 & -8.122728 & -4.984692 \\
\hline dum93 & -11.55236 & 1.130583 & -10.22 & 0.000 & -13.76826 & -9.336453 \\
\hline dum94 & -10.96545 & 1.108345 & -9.89 & 0.000 & -13.13777 & -8.793136 \\
\hline dum95 & -11.53966 & 1.146819 & -10.06 & 0.000 & -13.78738 & $\begin{array}{l}-9.291937 \\
\end{array}$ \\
\hline dum96 & -12.21969 & 1.217345 & -10.04 & 0.000 & -14.60565 & -9.833743 \\
\hline dum97 & -17.24955 & 1.666793 & -10.35 & 0.000 & -20.5164 & -13.9827 \\
\hline dum98 & -18.06956 & 1.842026 & $\begin{array}{l}-10.81 \\
-9.81\end{array}$ & 0.000 & -21.67987 & -14.45926 \\
\hline dum99 & -26.13827 & 2.501743 & -10.45 & 0.000 & -31.04159 & -21.23494 \\
\hline gdpvar & -.5333371 & .1683228 & -3.17 & 0.002 & -.8632436 & -.2034305 \\
\hline cons & $\begin{array}{l}-.00 .12394 \\
-90\end{array}$ & 7.202303 & -12.51 & 0.000 & $\begin{array}{r}.004 .2402 \\
-104.24\end{array}$ & $\begin{array}{l}-76.00769 \\
-76.00\end{array}$ \\
\hline Fathrho & 205.1497 & 46.23187 & 4.44 & 0.000 & 114.5369 & 295.7625 \\
\hline rho & 1 & 0 & & & & 1 \\
\hline 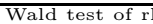 & & & & & Prob > & $=0.0000$ \\
\hline
\end{tabular}


Table A.10

Bi-Variate Probit Model Supposing Full Observability (Sector 5)

biprobit fire quit gender head age educ tenure contr. open_unemp dec 88 dum 90 dum91 dum92 dum93 dum94 dum95 dum96 dum97 dum98 dum99 gdpvar;

\begin{tabular}{|c|c|c|c|c|c|c|}
\hline \multicolumn{5}{|c|}{ Bivariate probit regression } & \multicolumn{2}{|c|}{ Number of obs $=186167$} \\
\hline & Coeff. & Std. Err. & $z$ & $P>|z|$ & {$[95 \% \mathrm{Cc}$} & Interval] \\
\hline fire & & & & & & \\
\hline gender & .0875071 & .0125639 & 6.96 & 0.000 & .0628823 & .1121319 \\
\hline head & .0461325 & .0142416 & 3.24 & 0.001 & .0182195 & .0740454 \\
\hline age & .0152634 & .0005509 & 27.71 & 0.000 & .0141836 & .0163431 \\
\hline educ & .0730478 & .0029504 & 24.76 & 0.000 & .0672652 & .0788305 \\
\hline tenure & .0094979 & .0001568 & 60.59 & 0.000 & .0091907 & .0098052 \\
\hline contr. & .6273701 & .0487223 & 12.88 & 0.000 & .5318762 & .722864 \\
\hline open_unemp & -.4728512 & .0108887 & -43.43 & 0.000 & -.4941927 & -.4515097 \\
\hline $\operatorname{dec} 88$ & .2399117 & .0498906 & 4.81 & 0.000 & .1421279 & .3376955 \\
\hline dum90 & -.2745807 & .0286486 & -9.58 & 0.000 & -.3307308 & -.2184305 \\
\hline dum91 & .1045842 & .0269695 & 3.88 & 0.000 & .051725 & .1574434 \\
\hline dum92 & .445338 & .0324322 & 13.73 & 0.000 & .3817721 & .508904 \\
\hline dum93 & .7051495 & .0345311 & 20.42 & 0.000 & .6374697 & .7728293 \\
\hline dum94 & .6320125 & .0334308 & 18.91 & 0.000 & .5664894 & .6975355 \\
\hline dum95 & .5277366 & .0335192 & 15.74 & 0.000 & .4620401 & .5934331 \\
\hline dum96 & .8522529 & .0388757 & 21.92 & 0.000 & .7760579 & .9284479 \\
\hline dum97 & $\begin{array}{l}.969753 \\
.963\end{array}$ & .0417931 & 23.20 & 0.000 & .8878399 & 1.051666 \\
\hline dum98 & 1.485022 & .0533103 & 27.86 & 0.000 & 1.380535 & 1.589508 \\
\hline dum99 & 2.124014 & .0615638 & 34.50 & 0.000 & 2.003351 & 2.244677 \\
\hline gdpvar & -.7484837 & .9525858 & -0.79 & 0.432 & -2.615517 & 1.11855 \\
\hline -cons & 3.387921 & .0814288 & 41.61 & 0.000 & 3.228324 & 3.547519 \\
\hline quit & & & & & & \\
\hline gender & -.1426336 & .0154037 & -9.26 & 0.000 & -.1728243 & -.1124429 \\
\hline head & .1080326 & .0188759 & 5.72 & 0.000 & .0710364 & .1450288 \\
\hline age & .0251968 & .0007423 & 33.94 & 0.000 & .0237419 & .0266517 \\
\hline educ & .0718111 & .003818 & 18.81 & 0.000 & .0643278 & .0792943 \\
\hline tenure & .0126323 & .0002535 & $\begin{array}{l}49.83 \\
9\end{array}$ & 0.000 & .0121355 & .0131292 \\
\hline contr. & 1.134731 & .0605985 & 18.73 & 0.000 & 1.01596 & 1.253502 \\
\hline open_unemp & -.2591108 & .0132973 & -19.49 & 0.000 & -.285173 & $\begin{array}{r}-.2330485 \\
\end{array}$ \\
\hline $\operatorname{dec} 88$ & .1989715 & .064184 & 3.10 & 0.002 & .0731732 & .3247697 \\
\hline dum90 & -.0506379 & .0312949 & -1.62 & 0.106 & -.1119748 & .0106991 \\
\hline dum91 & .2780664 & .0301947 & 9.21 & 0.000 & .2188859 & .337247 \\
\hline dum92 & .4728483 & .037968 & 12.45 & 0.000 & .3984324 & .5472642 \\
\hline dum93 & .6324841 & .0404372 & 15.64 & 0.000 & .5532287 & .7117396 \\
\hline dum94 & .5673132 & .038821 & 14.61 & 0.000 & .4912255 & .6434009 \\
\hline dum95 & .5191628 & .0392642 & 13.22 & 0.000 & .4422064 & .5961191 \\
\hline dum96 & .876128 & .0470892 & 18.61 & 0.000 & .7838348 & .9684211 \\
\hline dum97 & .9797305 & .0507952 & 19.29 & 0.000 & .8801738 & 1.079287 \\
\hline dum98 & 1.275958 & .0651999 & 19.57 & 0.000 & 1.148168 & 1.403747 \\
\hline dum99 & 1.720312 & .0761063 & 22.60 & 0.000 & 1.571146 & 1.869477 \\
\hline gdpvar & -12.08746 & 1.096113 & -11.03 & 0.000 & -14.2358 & -9.939117 \\
\hline -cons & 1.707142 & .0999568 & 17.08 & 0.000 & 1.51123 & 1.903053 \\
\hline fathrho & -1.312825 & .0348786 & -37.64 & 0.000 & -1.381185 & -1.244464 \\
\hline rho & -.8649884 & .0087822 & & & -.8812164 & -.8467239 \\
\hline
\end{tabular}


Table A.11

Bi-Variate Probit Model With Partial Observability (Sector 5)

biprobit fire quit gender head age educ tenure contr. open_unemp dec 88 dum 90

dum91 dum92 dum93 dum94 dum95 dum96 dum97 dum98 dum99 gdpvar, partial difficult from coefss);

\begin{tabular}{|c|c|c|c|c|c|c|}
\hline \multicolumn{5}{|c|}{$\begin{array}{l}\text { Partial observability bivariate probit } \\
\text { Log likelihood }=-19614.812\end{array}$} & \multicolumn{2}{|c|}{$\begin{array}{r}\text { Number of obs }=186167 \\
\text { Wald chi2 }(38)=22249.94 \\
\text { Prob }>\text { chi2 }=0.0000\end{array}$} \\
\hline & Coeff. & Std. Err. & $z$ & $P>|z|$ & {$[95 \% \mathrm{Co}$} & Interval] \\
\hline \multicolumn{7}{|c|}{ 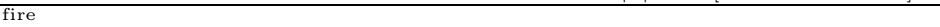 } \\
\hline gender & .0252443 & .0185739 & 1.36 & 0.174 & -.0111599 & .0616484 \\
\hline head & .0737479 & .0211777 & 3.48 & 0.000 & .0322404 & .1152554 \\
\hline age & .0224392 & .0008278 & 27.11 & 0.000 & .0208166 & .0240617 \\
\hline educ & .087388 & .0043873 & 19.92 & 0.000 & .0787891 & .0959869 \\
\hline tenure & .0102169 & .000219 & 46.66 & 0.000 & .0097877 & .0106461 \\
\hline contr. & .4278629 & .0617188 & 6.93 & 0.000 & .3068963 & .5488296 \\
\hline open_unemp & -3.830774 & .0378545 & -101.20 & 0.000 & -3.904967 & -3.75658 \\
\hline $\operatorname{dec} 88$ & .69567 & .0638978 & 10.89 & 0.000 & .5704326 & .8209073 \\
\hline dum90 & .6016875 & .0444485 & 13.54 & 0.000 & .5145701 & .6888048 \\
\hline dum91 & 3.13013 & .052137 & 60.04 & 0.000 & 3.027943 & 3.232316 \\
\hline dum92 & 7.237571 & .079901 & 90.58 & 0.000 & 7.080967 & 7.394174 \\
\hline dum93 & 8.485782 & .0897859 & 94.51 & 0.000 & 8.309805 & 8.661759 \\
\hline dum94 & 7.065091 & .0777212 & 90.90 & 0.000 & 6.912761 & 7.217422 \\
\hline dum95 & 7.597464 & .0864266 & 87.91 & 0.000 & 7.428071 & 7.766857 \\
\hline dum96 & 9.765077 & .1066981 & 91.52 & 0.000 & 9.555953 & 9.974202 \\
\hline dum97 & 10.91536 & .1133713 & 96.28 & 0.000 & 10.69316 & 11.13757 \\
\hline dum98 & 16.37847 & .1696443 & 96.55 & 0.000 & 16.04598 & 16.71097 \\
\hline dum99 & 19.19894 & .1927019 & 99.63 & 0.000 & 18.82125 & 19.57663 \\
\hline gdpvar & 167.3992 & 2.901519 & 57.69 & 0.000 & 161.7123 & 173.0861 \\
\hline -cons & 26.08786 & .2634686 & 99.02 & 0.000 & 25.57147 & 26.60425 \\
\hline \multicolumn{7}{|l|}{ quit } \\
\hline gender & .0166432 & .0300095 & 0.55 & 0.579 & -.0421743 & .0754606 \\
\hline head & .1153864 & .0347474 & 3.32 & 0.001 & .0472828 & .18349 \\
\hline age & .0209884 & .0013314 & 15.76 & 0.000 & .0183789 & .023598 \\
\hline educ & .087339 & .0070766 & 12.34 & 0.000 & .0734692 & .1012089 \\
\hline tenure & .010407 & .0003552 & 29.30 & 0.000 & .0097108 & .0111032 \\
\hline contr. & .7713329 & .1119557 & 6.89 & 0.000 & .5519037 & .9907621 \\
\hline open_unemp & 8.505176 & .1161353 & 73.24 & 0.000 & 8.277555 & 8.732797 \\
\hline $\operatorname{dec} 88$ & .3641379 & .1161513 & 3.14 & 0.002 & .1364855 & .5917902 \\
\hline dum90 & $\begin{array}{l}-.4597141 \\
-.04\end{array}$ & .0645743 & $\begin{array}{l}0.14 \\
-7.12\end{array}$ & 0.000 & $\begin{array}{l}-.5862774 \\
-\end{array}$ & $\begin{array}{l}-.3331508 \\
-\end{array}$ \\
\hline dum91 & -10.25545 & .1501449 & -68.30 & 0.000 & -10.54973 & -9.961168 \\
\hline dum92 & -12.14735 & .165538 & -73.38 & 0.000 & -12.47179 & -11.8229 \\
\hline dum93 & -21.21793 & .2928022 & -72.47 & 0.000 & -21.79181 & -20.64405 \\
\hline dum94 & -20.0262 & .2781965 & -71.99 & 0.000 & -20.57146 & -19.48095 \\
\hline dum95 & -19.45789 & .2717187 & -71.61 & 0.000 & -19.99045 & -18.92533 \\
\hline dum96 & -25.1616 & .3407653 & -73.84 & 0.000 & -25.82949 & -24.49371 \\
\hline dum97 & -27.72717 & .3923401 & -70.67 & 0.000 & -28.49614 & -26.9582 \\
\hline dum98 & -34.13181 & .4609936 & -74.04 & 0.000 & -35.03534 & -33.22828 \\
\hline dum99 & -46.73714 & .6351597 & -73.58 & 0.000 & -47.98203 & -45.49225 \\
\hline gdpvar & -493.3109 & 6.814168 & -72.39 & 0.000 & -506.6664 & -479.9554 \\
\hline cons & -51.67976 & $\begin{array}{l}. .017042 \\
.7172\end{array}$ & $\begin{array}{l}-72.07 \\
-72.07\end{array}$ & 0.000 & -53.08513 & $\begin{array}{l}-50.27438 \\
\end{array}$ \\
\hline Fathrho & 251.8397 & 61.676 & 4.08 & 0.000 & 130.9569 & 372.7224 \\
\hline rho & 1 & 0 & & & 1 & \\
\hline 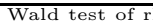 & & & & & & \\
\hline
\end{tabular}

